Prepared in cooperation with the Coachella Valley Water District

\title{
Detection and Measurement of Land Subsidence Using Global Positioning System Surveying and Interferometric Synthetic Aperture Radar, Coachella Valley, California, 1996-2005
}

Scientific Investigations Report 2007-5251

Version 2.0, June 2013 
Detection and Measurement of Land Subsidence Using Global Positioning System Surveying and Interferometric Synthetic Aperture Radar, Coachella Valley, California, 1996-2005

By Michelle Sneed and Justin T. Brandt

Prepared in cooperation with Coachella Valley Water District

Scientific Investigations Report 2007-5251

Version 2.0, June 2013

U.S. Department of the Interior

U.S. Geological Survey 


\title{
U.S. Department of the Interior DIRK KEMPTHORNE, Secretary
}

\author{
U.S. Geological Survey \\ Mark D. Myers, Director
}

U.S. Geological Survey, Reston, Virginia: 2007

Revised: 2013

For product and ordering information:

World Wide Web: http://www.usgs.gov/pubprod

Telephone: 1-888-ASK-USGS

For more information on the USGS--the Federal source for science about the Earth, its natural and living resources, natural hazards, and the environment:

World Wide Web: http://www.usgs.gov

Telephone: 1-888-ASK-USGS

Any use of trade, product, or firm names is for descriptive purposes only and does not imply endorsement by the U.S. Government.

Although this report is in the public domain, permission must be secured from the individual copyright owners to reproduce any copyrighted materials contained within this report.

Suggested reference:

Sneed, Michelle, and Brandt, Justin, 2007, Detection and Measurement of Land Subsidence Using Global Positioning System Surveying and Interferometric Synthetic Aperture Radar, Coachella Valley, California, 1996-2005: U.S. Geological Survey Scientific Investigations Report 2007-5251, 30 p. 


\section{Contents}

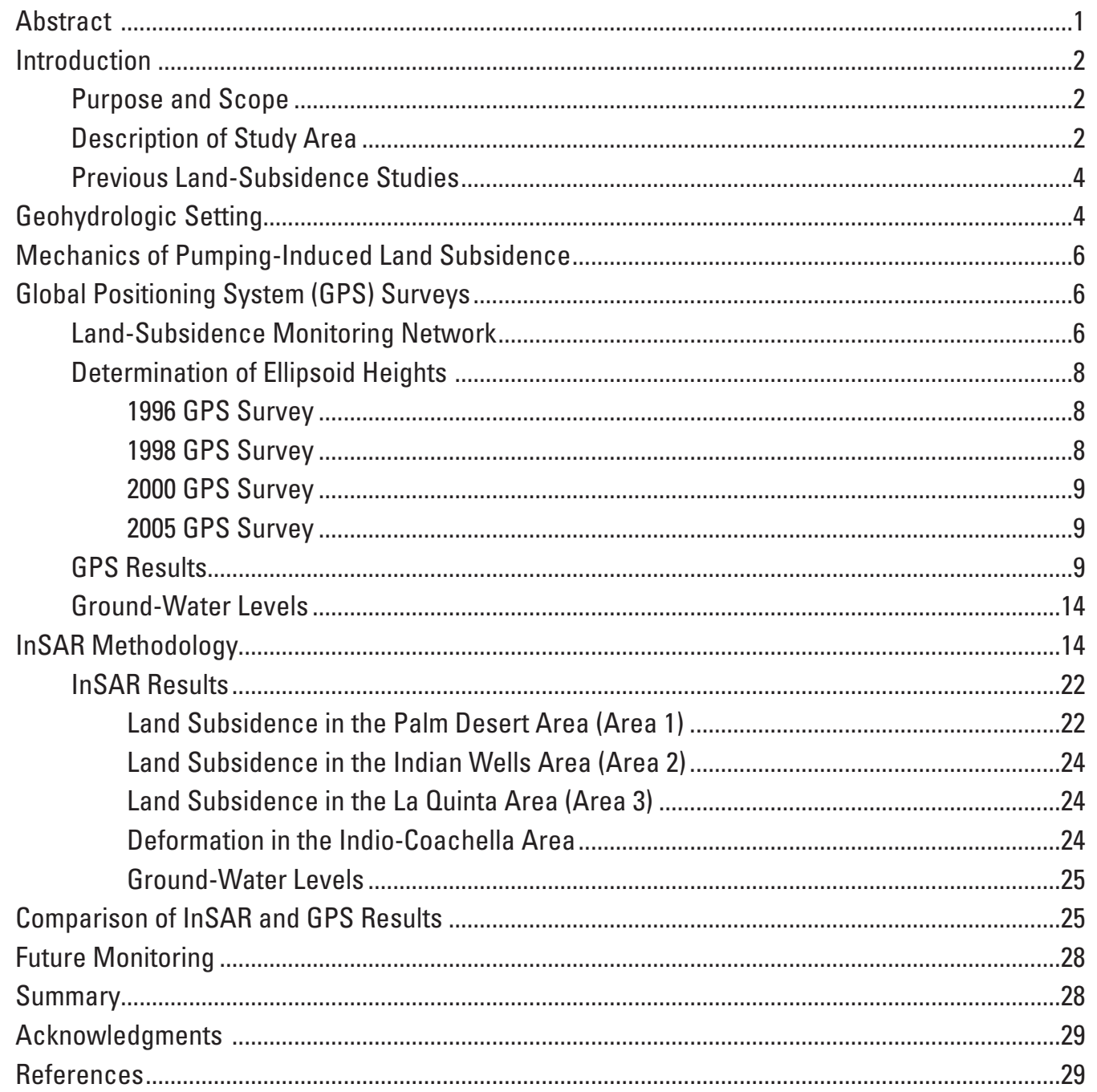




\section{Figures}

Figure 1. Map showing location of study area and of six Continuous Global Positioning System (CGPS) stations in or near Coachella Valley, California. ................. 3

Figure 2. Map showing generalized geology of the Coachella Valley, California............. 5

Figure 3. Map showing network of Global Positioning System (GPS) stations and wells used to monitor vertical changes in land surface and ground-water levels, respectively, in the southern Coachella Valley, California.

Figure 4. Hydrographs showing (A) water-surface elevations for selected wells (between 1995 and 2005), and ellipsoid-height changes (relative to the first measurement) for geodetic monuments measured at least twice, and (B) water-surface elevations for a subset of the wells in A for 1925-2005.

Figure 5. Image showing land-surface features, consolidated rock, Global Positioning System (GPS) stations, two Continuous Global Positioning System (CGPS) stations, three areas of subsidence, and selected roads and production wells, Coachella Valley, California.

Figure 6. Areas of subsidence, linearities at subsidence margins, consolidated rock, GPS stations, and two CGPS stations in the Coachella Valley, California, for November 30, 2003, through May 23, 2004, (A) as shown on the interferogram, and (B) as shown by subsidence contours interpreted from the interferogram in $A$.

Figure 7. Areas of subsidence, consolidated rock, GPS stations, and two CGPS stations in the Coachella Valley, California, for August 1, 2004, through September 5, 2004, (A) as shown on the interferogram, and (B) as shown by subsidence contours interpreted from the interferogram in $A$.

Figure 8. Areas of subsidence, consolidated rock, GPS stations, and two CGPS stations in the Coachella Valley, California, for October 26, 2003, through June 12, 2005, (A) as shown on the interferogram, and $(B)$ as shown by subsidence contours interpreted from the interferogram in $A$.

Figure 9. Hydrographs showing $(A)$ water-surface elevations for selected production wells, and InSAR timeseries showing land subsidence for 5/7/2003-9/25/2005, and (B) water-surface elevations for the same production wells for 1970-2005 in the three InSAR-detected land subsidence areas in the Coachella Valley, California.

\section{Tables}

Table 1. Horizontal positions and ellipsoid heights for 1996, 1998, 2000, and 2005, and ellipsoid-height changes relative to the first measurement of geodetic monuments in the Coachella Valley, California.

Table 2. Vertical change measured using interferometric synthetic aperture radar (InSAR) for 3 areas in the Coachella Valley, California, 2003-2005. 


\section{Conversion Factors}

\begin{tabular}{|c|c|c|}
\hline Multiply & By & To obtain \\
\hline \multicolumn{3}{|c|}{ Length } \\
\hline centimeter $(\mathrm{cm})$ & 0.3937 & inch (in) \\
\hline millimeter (mm) & 0.03937 & inch (in) \\
\hline meter $(\mathrm{m})$ & 3.281 & foot $(\mathrm{ft})$ \\
\hline kilometer $(\mathrm{km})$ & 0.6214 & mile (mi) \\
\hline \multicolumn{3}{|c|}{ Area } \\
\hline square kilometer $\left(\mathrm{km}^{2}\right)$ & 0.3861 & square mile $\left(\mathrm{mi}^{2}\right)$ \\
\hline \multicolumn{3}{|c|}{ Rate } \\
\hline meter per day $(\mathrm{m} / \mathrm{d})$ & 3.281 & foot per day $(\mathrm{ft} / \mathrm{d})$ \\
\hline meter per year (m/yr) & 3.281 & foot per year (ft/yr) \\
\hline millimeter per day (mm/d) & 0.003281 & foot per day $(\mathrm{ft} / \mathrm{d})$ \\
\hline millimeter per month $(\mathrm{mm} / \mathrm{mo})$ & 0.003281 & foot per month $(\mathrm{ft} / \mathrm{mo})$ \\
\hline millimeter per year (mm/yr) & 0.03937 & inch per year (in/yr) \\
\hline kilometer per hour $(\mathrm{km} / \mathrm{h})$ & 0.6214 & mile per hour $(\mathrm{mi} / \mathrm{h})$ \\
\hline
\end{tabular}

Temperature in degrees Celsius $\left({ }^{\circ} \mathrm{C}\right)$ may be converted to degrees Fahrenheit $\left({ }^{\circ} \mathrm{F}\right)$ as follows:

$$
{ }^{\circ} \mathrm{F}=\left(1.8 \mathrm{x}^{\circ} \mathrm{C}\right)+32
$$

Vertical displacements determined by InSAR and coordinates determined by Global Positioning System (GPS) surveying generally are reported in metric units. The industry standard for GPS usage is that field measurements and subsequent computations, including standard error determinations, are done in the metric system. The use of dual units in this report is intended to facilitate application of the data by maintaining the integrity of the original units of measurement for GPS surveying.

Sea level: In this report, "sea level" refers to the National Geodetic Vertical Datum of 1929 (NGVD of 1929) - a geodetic datum derived from a general adjustment of the first-order level nets of both the United Sates and Canada, formerly called Sea Level Datum of 1929.

Ellipsoid heights: In this report, Global Positioning System (GPS) measurements of horizontal coordinates and ellipsoid heights are based on the North American Datum of 1983 (NAD83). 


\title{
Abbreviations and Acronyms
}

\author{
Caltrans California Department of Transportation \\ CGPS Continuous Global Positioning System \\ CVWD Coachella Valley Water District \\ DEM digital elevation model \\ ESA European Space Agency \\ GPS Global Positioning System \\ IGS International GPS Service \\ InSAR Interferometric Synthetic Aperture Radar \\ NGS National Geodetic Survey \\ SAR Synthetic Aperture Radar \\ SCIGN Southern California Integrated GPS Network \\ SOPAC Scripps Orbit and Permanent Array Center \\ UNAVCO University NAVSTAR (Navigation Signal Timing and Ranging) Consortium \\ USGS United States Geological Survey
}




\section{Well-Numbering System}

Wells are identified and numbered according to their location in the rectangular system for the subdivision of public lands. Identification consists of the township number, north or south; the range number, east or west; and the section number. Each section is divided into sixteen 40 -acre tracts lettered consecutively (except I and 0), beginning with "A" in the northeast corner of the section and progressing in a sinusoidal manner to " $\mathrm{R}$ " in the southeast corner. Within the 40 -acre tract, wells are sequentially numbered in the order they are inventoried. The final letter refers to the base line and meridian. In California, there are three base lines and meridians; Humboldt $(\mathrm{H})$, Mount Diablo (M), and San Bernardino (S). All wells in the study area are referenced to the San Bernardino base line and meridian (S) Well numbers consist of 15 characters and follow the format 005S006E23K002S. In this report, well numbers are abbreviated and written 5S/6E-23K2. Wells in the same township and range are referred to only by their section designation, $23 \mathrm{~K} 2$. The following diagram shows how the number for well 5S/6E-23K2 is derived.

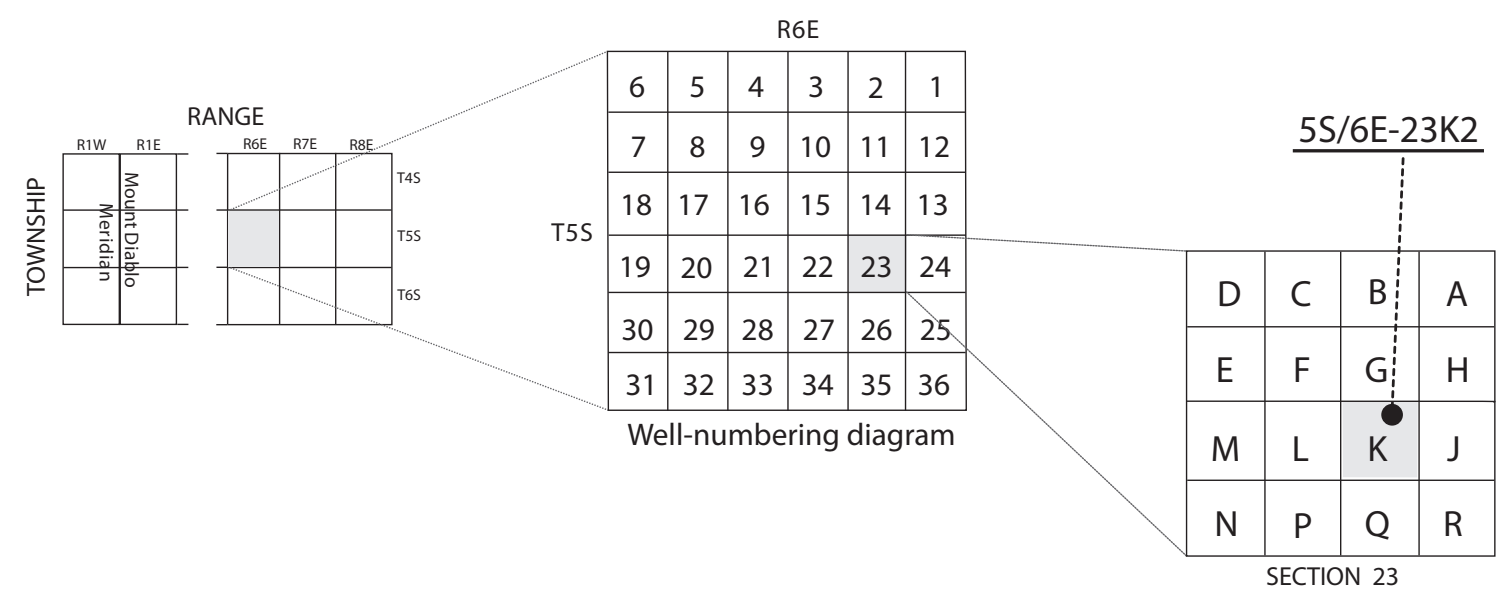


This page intentionally left blank. 


\title{
Detection and Measurement of Land Subsidence Using Global Positioning System Surveying and Interferometric Synthetic Aperture Radar, Coachella Valley, California, 1996-2005
}

\author{
By Michelle Sneed and Justin T. Brandt
}

\section{Abstract}

Land subsidence associated with ground-water-level declines has been investigated by the U.S. Geological Survey in the Coachella Valley, California, since 1996. Ground water has been a major source of agricultural, municipal, and domestic supply in the valley since the early 1920s. Pumping of ground water resulted in water-level declines as large as 15 meters (50 feet) through the late 1940s. In 1949, the importation of Colorado River water to the southern Coachella Valley began, resulting in a reduction in ground-water pumping and a recovery of water levels during the 1950s through the 1970s. Since the late 1970s, demand for water in the valley has exceeded deliveries of imported surface water, resulting in increased pumping and associated ground-waterlevel declines and, consequently, an increase in the potential for land subsidence caused by aquifer-system compaction.

Global Positioning System (GPS) surveying and interferometric synthetic aperture radar (InSAR) methods were used to determine the location, extent, and magnitude of the vertical land-surface changes in the southern Coachella Valley. GPS measurements made at 13 geodetic monuments in 1996 and in 2005 in the southern Coachella Valley indicate that the elevation of the land surface had a net decline of 124 to $9 \mathrm{~mm}$ $\pm 54 \mathrm{~mm}(0.41$ to $0.03 \mathrm{ft} \pm 0.18 \mathrm{ft})$ during the 9-year period. Changes at 9 of the 13 monuments exceeded the maximum expected uncertainty of $\pm 54 \mathrm{~mm}( \pm 0.18 \mathrm{ft})$ at the 95 -percent confidence level, indicating that subsidence occurred at these monuments between June 1996 and August 2005. GPS measurements made at 20 geodetic monuments in 2000 and in 2005 indicate that the elevation of the land surface changed -192 to $+51 \mathrm{~mm} \pm 36 \mathrm{~mm}(-0.63$ to $+0.17 \mathrm{ft} \pm 0.12 \mathrm{ft})$ during the 5 -year period. Changes at 6 of the 20 monuments exceeded the maximum expected uncertainty of $\pm 36 \mathrm{~mm}( \pm 0.12 \mathrm{ft})$ at the 95-percent confidence level-subsidence occurred at five monuments and uplift occurred at one monument between August 2000 and August 2005. GPS measurements at two of the five subsiding monuments for which subsidence rates could be compared indicate that subsidence rates decreased during this period compared with subsidence rates before 2000.

InSAR measurements made between May 7, 2003, and September 25, 2005, indicate that land subsidence, ranging from about 75 to 180 millimeters ( 0.25 to 0.59 foot), occurred in three areas of the Coachella Valley: near Palm Desert, Indian Wells, and La Quinta; the equivalent subsidence rates range from about 3 to more than $6 \mathrm{~mm} /$ month $(0.01$ to $0.02 \mathrm{ft} / \mathrm{month})$. The subsiding areas near Palm Desert, Indian Wells, and La Quinta were previously identified using InSAR measurements for 1996-2000, which indicated that about 35 to $150 \mathrm{~mm}(0.11$ to $0.49 \mathrm{ft})$ of subsidence occurred during the four-year period; the equivalent subsidence rates range from about 1 to $3 \mathrm{~mm} /$ month ( 0.003 to $0.01 \mathrm{ft} / \mathrm{month})$. Comparison of the InSAR results indicates that subsidence rates have increased 2 to 4 times since 2000 in these three areas.

Water-level measurements made at wells near the subsiding monuments and in the three subsiding areas generally indicated that the water levels fluctuated seasonally and declined annually between 1996 and 2005; some water levels in 2005 were at the lowest levels in their recorded histories. The coincident areas of subsidence and declining water levels suggest that aquifer-system compaction may be causing subsidence. If the stresses imposed by the historically lowest water levels exceeded the preconsolidation stress, the aquifer-system compaction and associated land subsidence may be permanent. Although the localized character of the subsidence signals is typical of the type of subsidence characteristically caused by localized ground-water pumping, the subsidence may also be related to tectonic activity in the valley. 


\section{Introduction}

Ground water has been a major source of agricultural, municipal, and domestic water supply in Coachella Valley, California (fig. 1), since the early 1920s. Pumping of ground water resulted in water-level declines as large as $15 \mathrm{~m}$ (50 ft) between the early 1920s and late 1940s. In 1949, the importation of Colorado River water through the Coachella Branch of the All-American Canal to the southern Coachella Valley began. As a result of the importation of surface water, pumping of ground water decreased in the southern Coachella Valley during the 1950s through the 1970s, and water levels in some wells in the lower valley recovered as much as $15 \mathrm{~m}$ $(50 \mathrm{ft})$. Since the late 1970s, however, the demand for water in the southern Coachella Valley has exceeded the deliveries of imported surface water, pumping has increased, and water levels have again declined. By 2005, water levels in many wells in the southern Coachella Valley had declined 15 to $30 \mathrm{~m}$ (50 to $100 \mathrm{ft}$ ) and water levels in some wells were at their lowest recorded levels.

Declining water levels can contribute to, or induce, land subsidence in aquifer systems that consist of a significant fraction of unconsolidated fine-grained sediments (silts and clays). Ikehara and others (1997) reported that as much as $150 \mathrm{~mm} \pm 90 \mathrm{~mm}(0.5 \mathrm{ft} \pm 0.3 \mathrm{ft})$ of subsidence occurred in the southern parts of the Coachella Valley between 1930 and 1996. Land subsidence can disrupt surface drainage; cause earth fissures; and damage wells, buildings, roads, and utility infrastructure. A large earth fissure was discovered in 1948 about $3 \mathrm{~km} \mathrm{(2} \mathrm{mi)} \mathrm{north} \mathrm{of} \mathrm{Lake} \mathrm{Cahuilla} \mathrm{in} \mathrm{La} \mathrm{Quinta.}$ Because subsidence had not been documented in the southern parts of the Coachella Valley prior to the report by Ikehara and others (1997), it is not known if this fissure formed in response to differential land subsidence during the earlier period (early 1920s-late 1940s) of ground-water-level declines. However, fissuring is recurring in this area (Clay Stevens, TerraPacific Consultants, Inc., written commun., 2006). Subsidencerelated earth fissures and reactivated surface faults have been identified in many other ground-water basins in the western United States (Holzer, 1984).

The Coachella Valley Water District (CVWD) works cooperatively with local stakeholders to manage the water supply for a large part of the Coachella Valley (fig. 1). Because of the potential for ground-water pumping to cause land subsidence, the CVWD entered into a cooperative agreement with the U.S. Geological Survey (USGS) to monitor vertical changes in land surface to determine if land subsidence was occurring in the Coachella Valley. In 1996, the USGS, in cooperation with CVWD, established a geodetic network of monuments to monitor vertical changes in land surface in the southern Coachella Valley using Global Positioning System (GPS) surveys and to establish baseline values for comparisons with results of future surveys.
The geodetic network needs to be surveyed intermittently to determine the distribution and amount of land subsidence. In addition, interferometric synthetic aperture radar (InSAR) data collected since 1996 have been used to detect and quantify land subsidence in areas removed from the geodetic monuments.

\section{Purpose and Scope}

The objectives of this study are to detect and quantify land subsidence that has occurred in the Coachella Valley from 1996 through 2005 by completing GPS surveys at the established geodetic network of monuments and by using InSAR data. This report presents the results and interpretations of GPS data collected at the monuments in the monitoring network during surveys in 1996, 1998, 2000, and 2005, and also of spatially detailed maps of vertical land-surface changes generated using InSAR data collected between 1996 and 2005. The InSAR-generated maps extend from near Palm Springs to near the Salton Sea (fig. 1). Data showing ground-waterlevel change during 1996-2005 were examined and compared with the GPS measurements and the InSAR-generated maps to determine if the vertical changes in land surface may be related to the changes in ground-water levels.

\section{Description of Study Area}

The Coachella Valley is a 100-km (65 mi) long, northwest-trending valley in southeastern California (fig. 1). The valley covers about $1,000 \mathrm{~km}^{2}\left(400 \mathrm{mi}^{2}\right)$ (California Department of Water Resources, 1964) and includes the cities of Cathedral City, Coachella, Desert Hot Springs, Indio, La Quinta, Palm Desert, Palm Springs, and Rancho Mirage. The valley is bordered by the San Jacinto and Santa Rosa Mountains on the west, the San Bernardino and the Little San Bernardino Mountains on the north, the Cottonwood Mountains and the Mecca Hills on the east, and the Salton Sea on the south (fig. 1). The Coachella Valley is drained primarily by the Whitewater River, which flows into the Whitewater Stormwater Channel and eventually discharges into the Salton Sea (fig. 1). Land-surface elevations vary from more than $70 \mathrm{~m}(230 \mathrm{ft})$ below sea level at the Salton Sea to more than $3,000 \mathrm{~m}(10,000 \mathrm{ft})$ above sea level at the peaks of the surrounding mountains.

The climate of the Coachella Valley floor is arid. Average annual rainfall ranges from $80 \mathrm{~mm}$ (3 in) on the valley floor to more than $760 \mathrm{~mm}$ (30 in) on the crests of the mountains to the west and north of the valley (California Department of Water Resources, 1964). Temperatures range from about $50^{\circ} \mathrm{C}$ $\left(120^{\circ} \mathrm{F}\right)$ on the valley floor in the summer to below $0^{\circ} \mathrm{C}\left(32^{\circ} \mathrm{F}\right)$ in the surrounding mountains in the winter. 


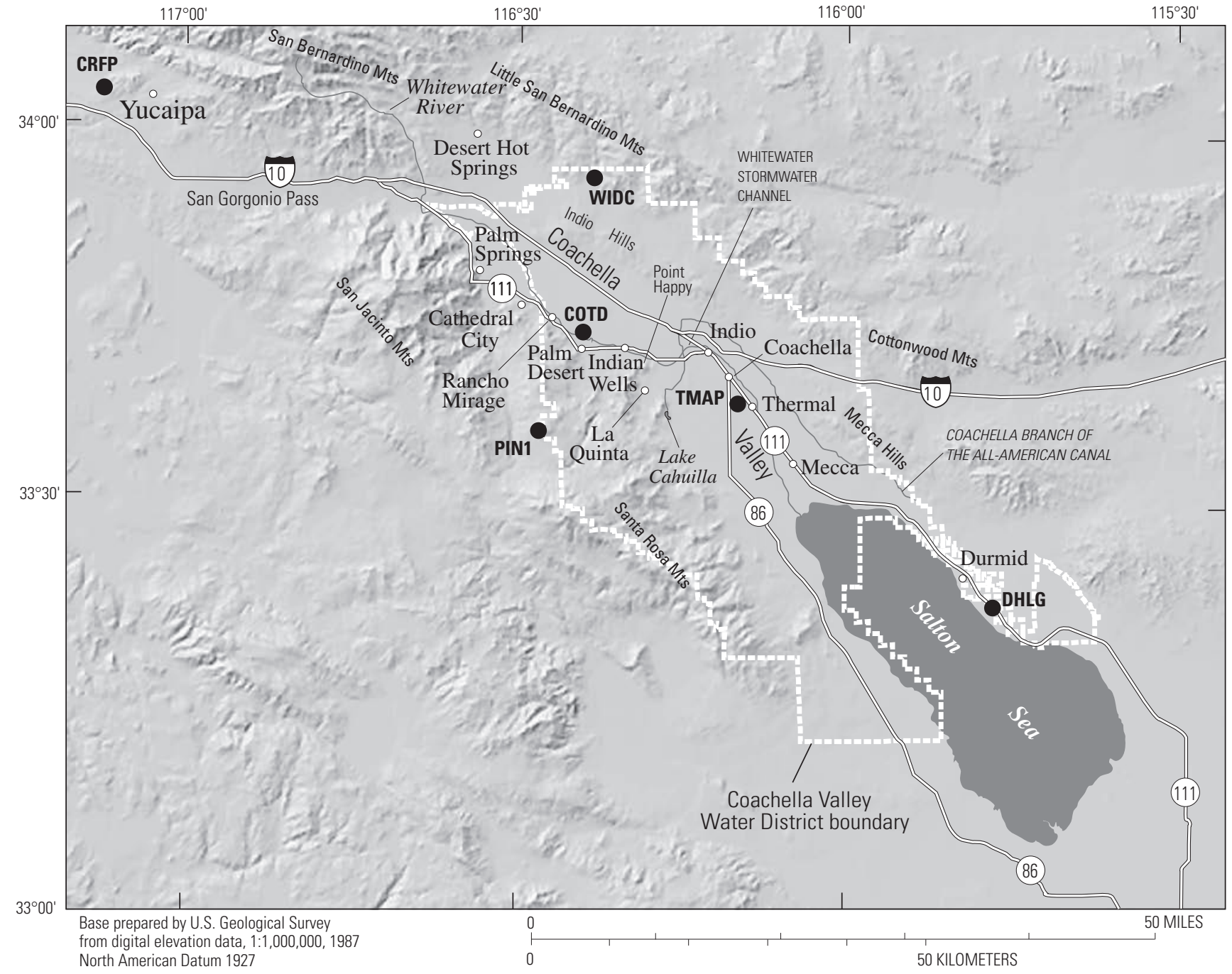

EXPLANATION

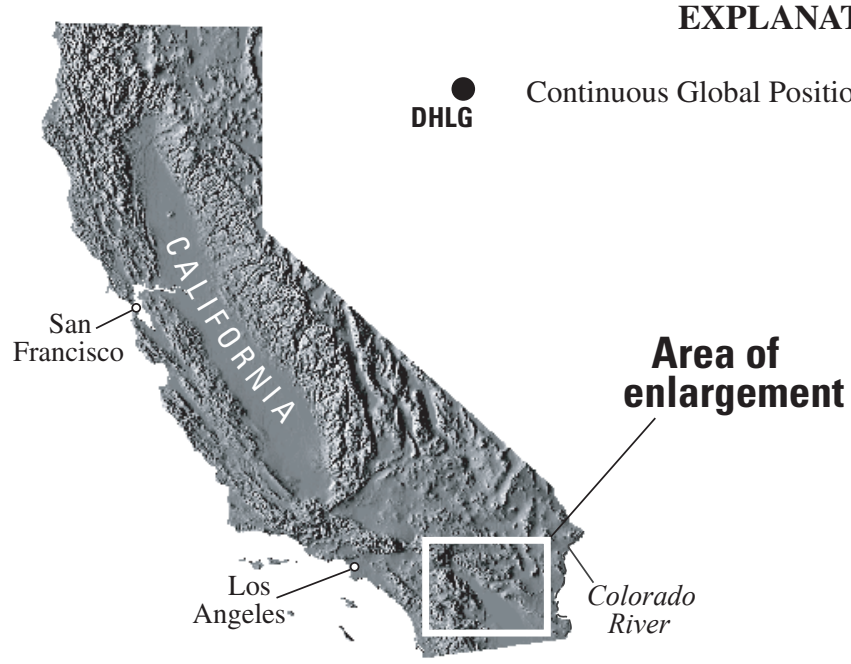

Figure 1. Map showing location of study area and of six Continuous Global Positioning System (CGPS) stations in or near Coachella Valley, California. 


\section{Previous Land-Subsidence Studies}

This study is the fourth in a series of Coachella Valley land-subsidence studies that have been completed by the USGS in cooperation with CVWD. Ikehara and others (1997) documented the development of the geodetic monitoring network and areas of possible land subsidence in Coachella Valley by comparing historical leveling measurements with GPS surveying measurements made in 1996. The vertical changes in land surface between 1996 and the earliest measurements at monuments in the monitoring network do not exceed $150 \mathrm{~mm}(0.5 \mathrm{ft})$ (Ikehara and others, 1997). The range of uncertainty ( $\pm 90 \mathrm{~mm}$ or $\pm 0.3 \mathrm{ft}$ ) of these calculated vertical changes in land surface, however, is large because the historical leveling surveys were done at different times and sometimes by different agencies using different methods. Furthermore, the methods used for the leveling surveys had different standards of accuracy and the networks were of different geographic extents (Ikehara and others, 1997). Sneed and others (2001) reported that GPS measurements indicated small amounts of subsidence between 1996 and 1998 at some monuments in the monitoring network; Sneed and others (2002) reported that GPS measurements indicated most monuments were fairly stable between 1998 and 2000 . Sneed and others $(2001,2002)$ also used InSAR to detect and quantify land subsidence throughout much of the Coachella Valley. InSAR measurements made between 1996 and 2000 indicated that as much as $150 \mathrm{~mm}(0.49 \mathrm{ft})$ of land subsidence occurred in areas near Palm Desert, Indian Wells, and La Quinta (Sneed, 2001, 2002).

\section{Geohydrologic Setting}

The Coachella Valley is the northernmost extent of the Salton Trough, which is the landward extension of a ridge/transform fault system (the East Pacific Rise) of the Gulf of California (McKibben, 1993). Near the end of the Miocene epoch, a spreading center separating the western Farallon plate from the eastern Pacific plate was obliquely subducted under the North American continent (McKibben, 1993). The modern Gulf of California and the Salton Trough formed about 12 million years ago during a period when subduction ceased and when the formation of an inland belt of east-west extension, alkali basalt volcanism, and crustalspreading-induced subsidence and basin sedimentation began (McKibben, 1993). Prior to about 6 million years ago, the shear zone constituting the principal tectonic boundary between the Pacific and North American plates appears to have shifted about $250 \mathrm{~km}(155 \mathrm{mi})$ inland into this belt, initiating the formation of the modern Gulf of California and the Salton Trough (McKibben, 1993). As the Salton Trough opened, it was filled with sediment from the delta of the Colorado River. The river has been building its delta from the east into the trough since about 5 million years ago, and sedimentation has apparently kept pace with the crustalspreading induced subsidence (McKibben, 1993). The relation between subsidence that has occurred on a geologic time scale, and vertical land-subsidence changes measured during this study are unknown.

The Coachella Valley is filled with as much as $3,700 \mathrm{~m}$ $(12,000 \mathrm{ft})$ of sediments; the upper $610 \mathrm{~m}(2,000 \mathrm{ft})$ are waterbearing (California Department of Water Resources, 1979). In this report, the water-bearing deposits are referred to as the aquifer system, which consists of a complex unconsolidated to partly consolidated assemblage of gravel, sand, silt, and clay of alluvial and lacustrine origins (fig. 2). Sediments tend to be finer grained (contain more silt and clay) in the southern part of the valley than in the northern part because of the greater depositional distance from mountain runoff and from lacustrine deposition from ancient Lake Cahuilla. In the southern Coachella Valley, the aquifer system consists of, from top to bottom: a semiperched zone that is fairly persistent southeast of Indio; an upper aquifer; a confining layer; and a lower aquifer (California Department of Water Resources, 1964, 1979).

The near-surface semiperched zone overlies the upper aquifer southeast of Indio and consists of silts, clays, and fine sand. The semiperched zone is as much as $30 \mathrm{~m}(100 \mathrm{ft})$ thick and generally is an effective barrier to deep percolation (California Department of Water Resources, 1964, 1979). The upper aquifer is present throughout the Coachella Valley and consists of unconsolidated and partly consolidated silty sands and gravels with interbeds of silt and clay. In general, the upper aquifer is 45 to $90 \mathrm{~m}$ ( 150 to $300 \mathrm{ft}$ ) thick. The aquifer is unconfined except where it is overlain by the semiperched zone, southeast of Indio. In the southern Coachella Valley, the upper aquifer is separated from the lower aquifer by a confining layer of silt and clay that is 30 to $60 \mathrm{~m}$ (100 to $200 \mathrm{ft}$ ) thick. The lower aquifer is the most productive source of ground water in the southern Coachella Valley; it consists of unconsolidated and partly consolidated silty sands and gravels with interbeds of silt and clay. The top of the lower aquifer is about 90 to $180 \mathrm{~m}$ (300 to $600 \mathrm{ft}$ ) below land surface. Available data indicate that the lower aquifer is at least $150 \mathrm{~m}$ $(500 \mathrm{ft})$ thick and may be as much as $600 \mathrm{~m}(2,000 \mathrm{ft})$ thick (California Department of Water Resources, 1964, 1979).

Geologic structures in the Coachella Valley have a marked influence on the occurrence and movement of ground water. The principal structural features of Coachella Valley are faults and fault-related drag and compressional folds. The most notable fault system is the northwest-trending San Andreas Fault Zone that flanks 


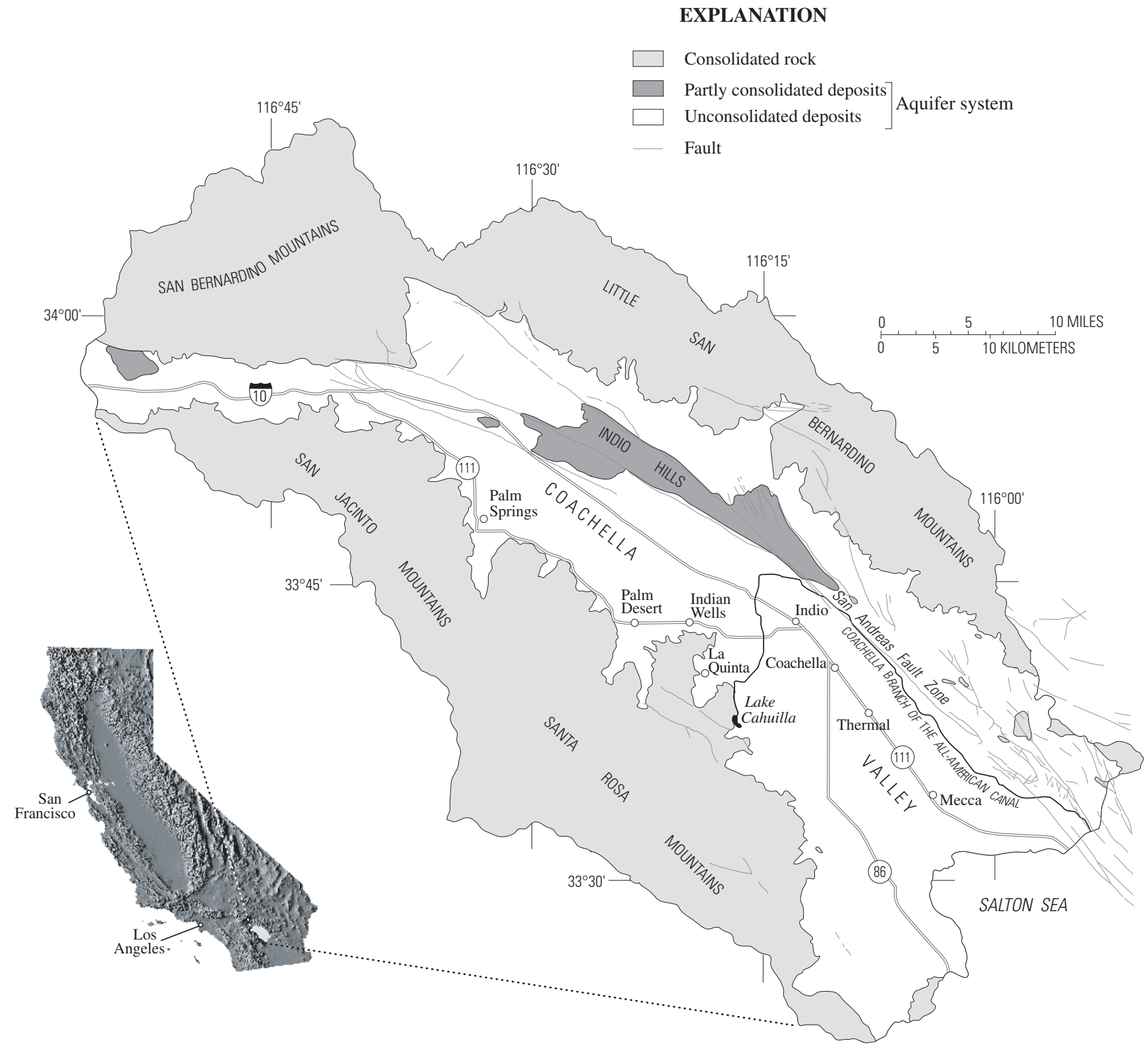

Figure 2. Map showing generalized geology of the Coachella Valley, California.

the eastern side of the valley (fig. 2). Although movement within the San Andreas Fault Zone is predominantly right lateral (across the fault, movement is to the right), vertical displacement has downdropped the southwest block (California Department of Water Resources, 1964). The faults have either juxtaposed consolidated rocks against partly consolidated or unconsolidated water-bearing deposits or displaced preferential flow paths in the partly consolidated or unconsolidated water-bearing deposits. This juxtaposition and displacement, in conjunction with cementation, compaction, and extreme deformation of water-bearing deposits adjacent to faults, can create low-permeability zones that can act as barriers to ground-water flow. 


\section{Mechanics of Pumping-Induced Land Subsidence}

Land subsidence is known to occur in valleys containing aquifer systems that are, at least in part, made up of finegrained sediments and that have undergone extensive groundwater development. The pore structure of a sedimentary aquifer system is supported by the granular skeleton of the aquifer system and the pore-fluid pressure of the ground water that fills the intergranular pore space (Meinzer, 1928). When ground water is withdrawn in quantities that result in reduced pore-fluid pressures and water-level declines, the reduction of the pore-fluid-pressure support increases the intergranular stress, or effective stress, on the skeleton. A change in effective stress deforms the skeleton - an increase in effective stress compresses it and a decrease in effective stress causes it to expand. The vertical component of this compression sometimes results in nonrecoverable compaction of the aquifer system and land subsidence. An aquifer-system skeleton that primarily consists of fine-grained sediments, such as silt and clay, is much more compressible than one that primarily consists of coarse-grained sediments, such as sand and gravel. Inelastic (nonrecoverable) compaction of coarse-grained sediment is negligible.

Aquifer-system deformation is elastic (recoverable) if the effective stress imposed on the skeleton is smaller than any previous effective stress (Leake and Prudic, 1991). The largest historical effective stress imposed on an aquifer system - sometimes as a result of the lowest ground-water level—is the "preconsolidation stress." If a stress imposed on the skeleton is greater than the preconsolidation stress, the pore structure of the granular matrix of the fine-grained sediments is rearranged; this new configuration results in a reduction of pore volume and, thus, inelastic (largely irreversible) compaction of the aquifer system. Furthermore, the compressibility of the fine-grained sediments, and any resulting compaction under stresses greater than the preconsolidation stress, are 20 to more than 100 times greater than they are under stresses less than the preconsolidation stress (Riley, 1998).

For an aquifer-system skeleton that contains an appreciable thickness of fine-grained sediments, a significant part of the total compaction may be residual compaction (delayed compaction that occurs in thick fine-grained interbeds and confining layers while heads equilibrate with heads in the adjacent aquifers [Terzaghi, 1925]). Depending on the thickness and the vertical hydraulic diffusivity of a confining layer, pressure equilibration - and thus compaction - lags behind pressure, or head, changes in the adjacent aquifers. For a more complete description of aquifersystem compaction, see Poland (1984), and for a review and selected case studies of land subsidence caused by aquifersystem compaction in the United States, see Galloway and others (1999).

\section{Global Positioning System (GPS) Surveys}

GPS is a U.S. Department of Defense satellite-based navigation system designed to provide continuous worldwide positioning and navigation capability. For this study, GPS surveys were done to determine the three-dimensional position of monuments in the geodetic monitoring network. The network was established in 1996 by the USGS to determine changes in land-surface elevations in the network (Ikehara and others, 1997) and to establish baseline values for comparisons with results of future surveys.

\section{Land-Subsidence Monitoring Network}

The geodetic monitoring network, henceforth referred to as the land-subsidence monitoring network, consists of geodetic monuments used as GPS stations (fig. 3). Most geodetic monuments are flat metal disks that are anchored in the ground or to a structure and that can be used in making repeated surveying measurements of horizontal and (or) vertical positions. During the 1996 study by Ikehara and others (1997), historical data for monuments in the southern Coachella Valley were compiled and reviewed to determine the location and the quality of the vertical-control data. Sources of the data include NOAA's (National Oceanic and Atmospheric Administration) National Geodetic Survey (NGS [formerly the U.S. Coast and Geodetic Survey]), the California Department of Transportation (Caltrans), the U.S. Bureau of Reclamation, and the CVWD (Ikehara and others, 1997). The geodetic monuments were examined before each of the GPS surveys in 1996, 1998, 2000, and 2005 to determine whether any had been damaged or destroyed and to evaluate their suitability for GPS observations.

The original subsidence monitoring network in the southern Coachella Valley was established in 1996 and consisted of 17 geodetic monuments. The network was modified for the 1998 GPS survey by replacing two monuments that had been destroyed (D1299 Tie [D12T] and Caltrans 14.3 Reset 1994 [C143]) with two nearby monuments (G70 1928 [G70] and Caltrans 13.21986 [C132]) (fig. 3). The network was again modified for the 2000 GPS survey because monument 54JA was horizontally unstable; the replacement monument (JA54) was installed about $6 \mathrm{~m}$ (20 ft) northwest of monument 54JA (fig. 3). In addition, four new monumentsMAGF, MANI, OSDO, and DEEP — were constructed and added in the Palm Desert and Indian Wells areas for the 2000 GPS survey (fig. 3) because the InSAR maps processed for 1996-2000 showed subsidence in these areas (Sneed and others, 2001, 2002). The monument SWC was destroyed by flooding in the Whitewater Stormwater Channel in early 2005, and thus could not be included in the 2005 survey (fig. 3). The spacing between the monuments meets the generalized network design criterion established by Zilkoski and others (1997), which requires that the distance between local network points not exceed $10 \mathrm{~km}$ (6 mi). 


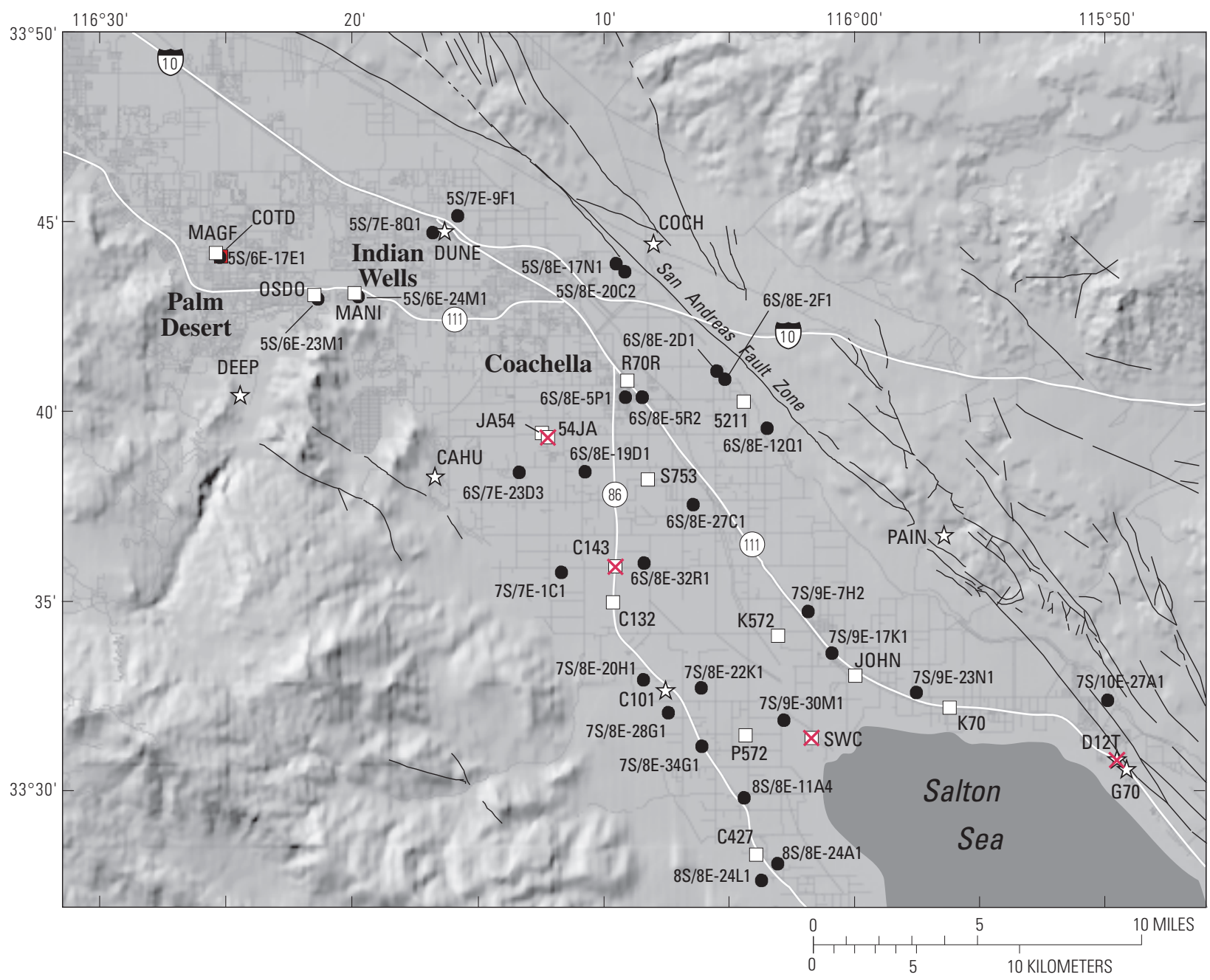

EXPLANATION

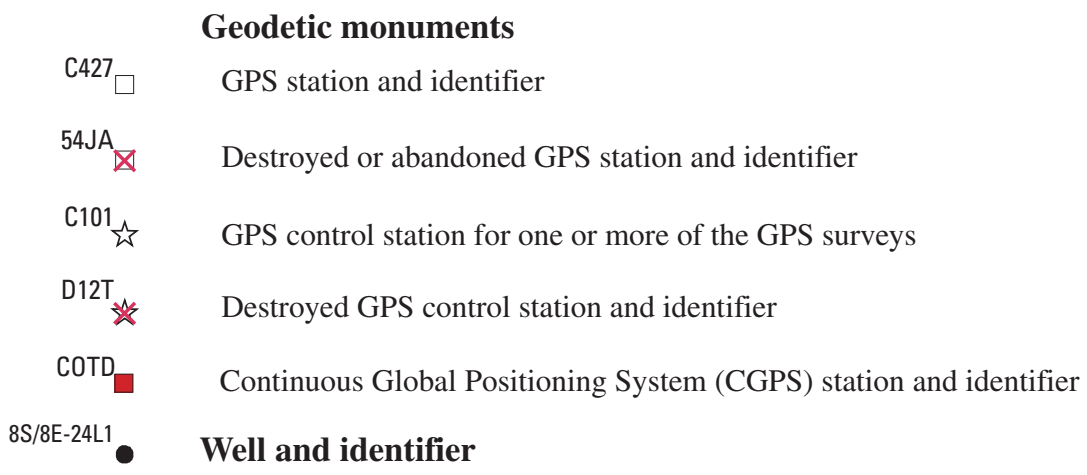

Figure 3. Map showing network of Global Positioning System (GPS) stations and wells used to monitor vertical changes in land surface and ground-water levels, respectively, in the southern Coachella Valley, California. 


\section{Determination of Ellipsoid Heights}

GPS measurements were made at the geodetic monuments to determine their horizontal positions and ellipsoid heights. Ellipsoid height is the vertical coordinate relative to a geodetically defined reference ellipse; the ellipsoid that closely approximates the Earth's shape in the study area is the North American Datum of 1983 (NAD83). To determine changes in ellipsoid heights, the heights from successive GPS surveys are compared; then, the differences in the heights are used to determine the location and magnitude of any vertical land-surface changes. The GPS surveying in 1996, 1998, 2000, and 2005 was done in accordance with "Guidelines for Establishing GPS-Derived Ellipsoid Height" by Zilkoski and others (1997) with one minor variation common to all 4 GPS surveys: single baseline, rather than multi-baseline, processing software was used for postprocessing. There are no known conclusive tests that objectively evaluate the effect of using single-baseline, rather than multi-baseline, processing software (Craymer and Beck, 1992). Other variations to the guidelines are specific to particular surveys and are described in the following sections. All of the GPS survey data were recomputed during this current study to eliminate the effects of variable processing methodologies used by assorted software and to standardize processing procedures for an improved comparison of threedimensional positions derived from data collected during each GPS survey. Software used for the baseline and least-squares adjustment computations was Trimble Geomatics Office version 1.63.

\section{GPS Survey}

GPS measurements for the 1996 survey were made using six dual-frequency, half-wavelength P-code GPS receivers (Ashtech LD-XII and Ashtech MD-XII) and choke-ring antennas (Dorne-Margolin) at the 17 geodetic monuments between June 3 and 14, 1996, to determine horizontal positions and ellipsoid heights (Ikehara and others, 1997). For this survey, the duration of the GPS measurements was nearly tripled compared with the duration specified by Zilkoski and others (1997) to compensate for using half-wavelength GPS receivers rather than the full-wavelength GPS receivers (Ikehara and others, 1997). GPS measurements were made at the 17 geodetic monuments on at least 2 different days, and data were recorded during 2.5- to 3-hour observation periods (Ikehara and others, 1997). Six of the 17 geodetic monuments - C101, CAHU, COCH, PAIN, D12T, and DUNE (fig. 3) - also were network control stations; GPS measurements were made at these six stations on 3 additional days, and data were recorded during 6-hour observation periods.

Determining the ellipsoid heights of the 17 geodetic monuments in the network involved two phases of leastsquares adjustments. During the first phase of least-squares adjustments, the horizontal coordinates and ellipsoid heights for the six Coachella Valley network control monuments were determined by processing the GPS measurements made at these monuments with measurements made simultaneously at three Continuous Global Positioning System (CGPS) stations (DHLG, PIN1, and CRFP) in southern California (fig. 1), and by using precise satellite orbital data and accurate coordinates of the CGPS stations produced by the International GPS Service (IGS) and the Scripps Orbit and Permanent Array Center (SOPAC), respectively. The GPS observations of the CGPS stations were recorded continually (at 30-second intervals), and were archived by SOPAC, a member of the Southern California Integrated GPS network (SCIGN). The network control monuments were selected on the basis of geographic distribution; they are at the perimeters of the monitoring network. During the second phase of least-squares adjustments, the positions of the six Coachella Valley network control monuments were held fixed at the positions determined during the first phase, and the horizontal coordinates and ellipsoid heights for the other 11 monuments were determined. The level of uncertainty for these heights is $\pm 50 \mathrm{~mm}( \pm 0.16 \mathrm{ft})$ at the 95 -percent confidence level.

\section{GPS Survey}

GPS measurements for the 1998 survey were made using five dual-frequency, full-wavelength P-code GPS receivers (Ashtech MD-XII) and choke-ring antennas (Dorne-Margolin) at the 17 geodetic monuments between October 5 and 9, 1998, to determine horizontal positions and ellipsoid heights. GPS measurements were made at the 17 geodetic monuments on at least 2 different days, and data were recorded during 45-minute observation periods. Five of the 17 geodetic monuments- $\mathrm{COCH}$, CAHU, PAIN, C101, and G70 (fig. 3) also were network control stations; GPS measurements were made at these five stations on 3 additional days, and data were recorded during 4.5 -hour observation periods.

Determining the ellipsoid heights of the 17 geodetic monuments in the network involved two phases of leastsquares adjustments. During the first phase of least-squares adjustments, horizontal coordinates and ellipsoid heights for the five Coachella Valley network control monuments were determined by processing the GPS measurements made at these monuments using measurements made simultaneously at three CGPS stations (DHLG, PIN1, and WIDC) in southern California (fig. 1), and by using precise satellite orbital data and accurate coordinates of the CGPS stations produced by IGS and SOPAC, respectively. The GPS observations of the CGPS stations were recorded continually (at 30-second intervals) and were archived by SOPAC. During the second phase of least-squares adjustments, the positions of the five Coachella Valley network control monuments were held fixed at the positions determined during the first phase, and the horizontal coordinates and ellipsoid heights for the other 12 monuments were determined. The level of uncertainty for these heights is $\pm 20 \mathrm{~mm}( \pm 0.07 \mathrm{ft})$ at a 95 -percent confidence level. 


\section{GPS Survey}

GPS measurements for the 2000 survey were made using six dual-frequency, full-wavelength, P-code GPS receivers (5 Trimble 4000SSIs and 1 Trimble 4000SSE) and compact L1/L2 Trimble antennas (with ground plane) at the 21 geodetic monuments between August 28 and September 1, 2000, to determine horizontal positions and ellipsoid heights. GPS measurements were made at the monuments on at least 2 different days, and data were recorded during 35 -minute observation periods. Six of the 21 geodetic monuments were used as network control stations- $\mathrm{COCH}$, DEEP, CAHU, PAIN, C101, and G70 (fig. 3). GPS measurements were made at these six stations on 3 additional days, and data were recorded during 5-hour observation periods.

Determining the ellipsoid heights of the 21 geodetic monuments in the network involved two phases of leastsquares adjustments. During the first phase of least-squares adjustments, horizontal coordinates and ellipsoid heights of the six Coachella Valley network control monuments were determined by processing the GPS measurements made at these monuments with measurements made simultaneously at the same three CGPS stations (DHLG, PIN1, and WIDC) used in processing the 1998 GPS survey data (fig. 1), and by using precise satellite orbital data and accurate coordinates of the CGPS stations produced by IGS and SOPAC, respectively. The GPS observation frequency of the CGPS stations was set at 30 seconds, and the observations were archived by SOPAC. During the second phase of least-squares adjustments, the positions of the six network control monuments were held fixed at the positions determined during the first phase, and the horizontal coordinates and ellipsoid heights for the other 15 monuments were determined. The accuracy of these ellipsoid heights is $\pm 20 \mathrm{~mm}( \pm 0.07 \mathrm{ft})$ at the 95 -percent confidence level.

\section{GPS Survey}

GPS measurements for the 2005 survey were made using six dual-frequency, full-wavelength, P-code GPS receivers (Topcon GB1000) and compact antennas (with ground plane) (Topcon PG-A1 Geodetic) at the 20 geodetic monuments between August 15 and 19, 2005, to determine horizontal positions and ellipsoid heights. GPS measurements were made at the monuments on at least 2 different days, and data were recorded during 1-hour observation periods. Six of the 20 geodetic monuments were used as network control stations- $\mathrm{COCH}$, DEEP, CAHU, PAIN, C101, and G70 (fig. 3); GPS measurements were made at these six stations on 3 additional days, and data were recorded during 6.5-hour observation periods.

Determining the ellipsoid heights of the 20 geodetic monuments in the network involved two phases of leastsquares adjustments. During the first phase of least-squares adjustments, horizontal coordinates and ellipsoid heights of the six Coachella Valley network control monuments were determined by processing the GPS measurements made at these monuments using measurements made simultaneously at the same three CGPS stations (DHLG, PIN1, and WIDC) used in processing both the 1998 and 2000 GPS survey data, and by using precise satellite orbital data and accurate coordinates of the CGPS stations produced by IGS and SOPAC, respectively. The GPS observation frequency of the CGPS stations was set at 30 seconds, and the observations were archived by SOPAC. During the second phase of least-squares adjustments, the positions of the six network control monuments were held fixed at the positions determined during the first phase, and the horizontal coordinates and ellipsoid heights for the other 14 monuments were determined. The accuracy of these ellipsoid heights is $\pm 20 \mathrm{~mm}( \pm 0.07 \mathrm{ft})$ at the 95 -percent confidence level.

\section{GPS Results}

The horizontal coordinates and the ellipsoid heights of the monuments determined from each of the four GPS surveys were compared to determine the magnitude of horizontal and vertical land-surface changes at the monuments, respectively. The horizontal changes at the monuments were consistent with the northwest movement of the Pacific Plate (with respect to the North American plate) (Shen, Z.-K. and others, 2003). The ellipsoid heights are given in table 1, and ellipsoid-height changes, adjusted to show ellipsoid height values relative to the first GPS measurement for a particular monument (that is, the first measurement was set to equal 0 ), are given in table 1 and shown in figure 4A.

Comparison of GPS measurements made at the 13 geodetic monuments surveyed in 1996 and in 2005 in the southern Coachella Valley indicate that the elevation of the land surface had a net decline of 124 to $9 \mathrm{~mm} \pm 54 \mathrm{~mm}(0.41$ to $0.03 \mathrm{ft} \pm 0.18 \mathrm{ft}$ ) during the 9 -year period (table 1). Changes at 9 of the 13 monuments (DUNE, R70R, 5211, CAHU, S753, K572, C101, P572, and C427) exceeded the maximum expected uncertainty of $\pm 54 \mathrm{~mm}( \pm 0.18 \mathrm{ft})$ at the 95 -percent confidence level, indicating that subsidence occurred at these monuments between June 1996 and August 2005. Changes at 4 of the 13 monuments (COCH, PAIN, JOHN, and K70) did not exceed the maximum expected uncertainty of $\pm 54 \mathrm{~mm}$ $( \pm 0.18 \mathrm{ft})$ at the 95 -percent confidence level, indicating that the vertical positions of these monuments in June 1996 and in August 2005 were similar.

Comparisons of GPS measurements made at 20 geodetic monuments in 2000 and in 2005 indicate that the elevation of the land surface changed -192 to $+51 \mathrm{~mm} \pm 36 \mathrm{~mm}(-0.63$ to $+0.17 \mathrm{ft} \pm 0.12 \mathrm{ft}$ ) during the 5-year period (table 1). Changes at 6 of the 20 monuments (MANI, MAGF, OSDO, R70R, JA54, and $\mathrm{COCH}$ ) exceeded the maximum expected uncertainty of $\pm 36 \mathrm{~mm}( \pm 0.12 \mathrm{ft})$ at the 95 -percent confidence level - subsidence occurred at five of these monuments (MANI, MAGF, OSDO, R70R, and JA54) and uplift occurred at $\mathrm{COCH}$ between August 2000 and August 2005. Changes at 14 of the 20 monuments (DEEP, DUNE, 5211, CAHU, S753, 


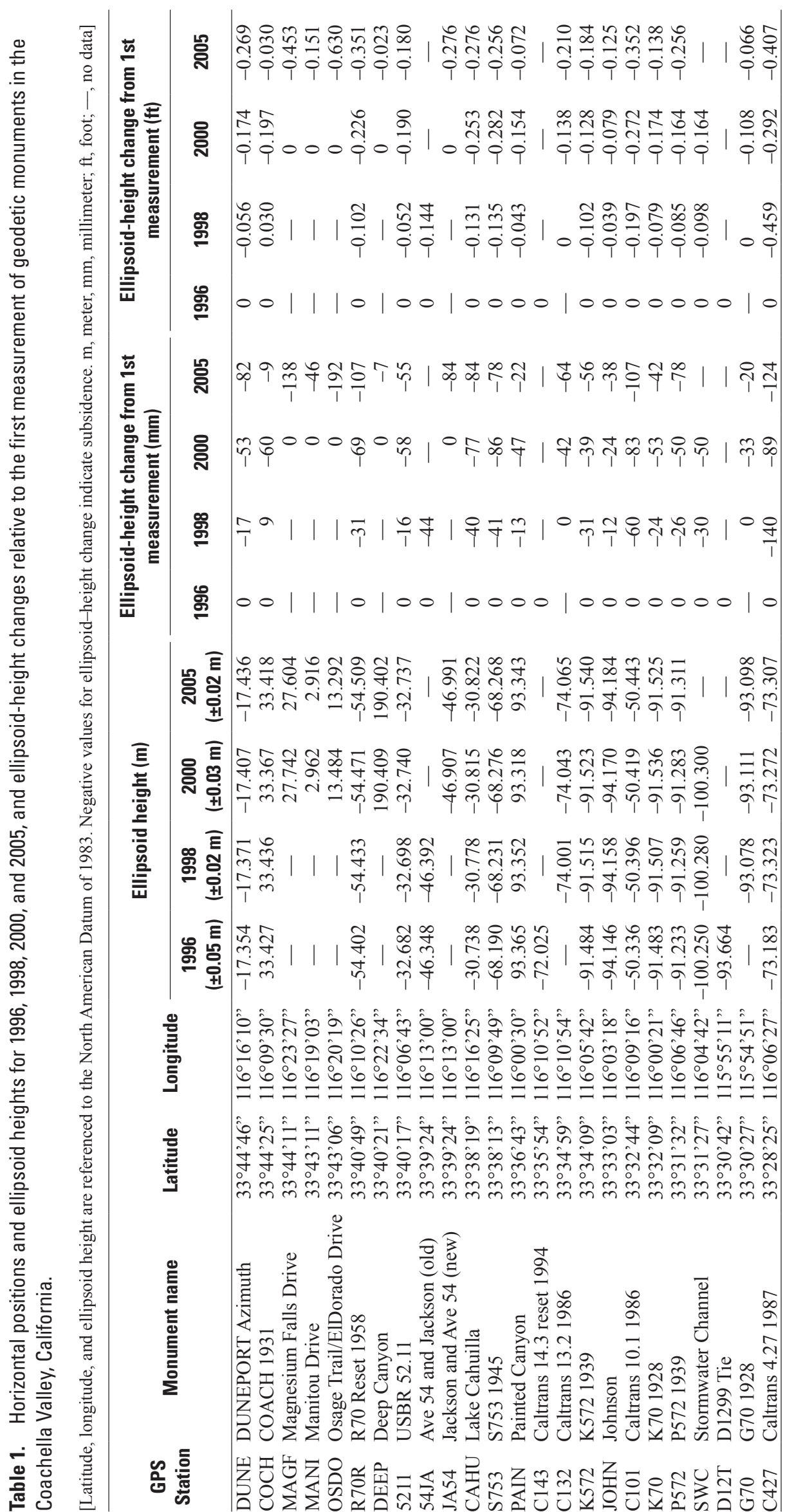




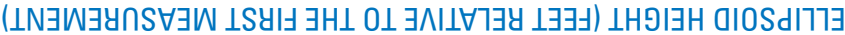
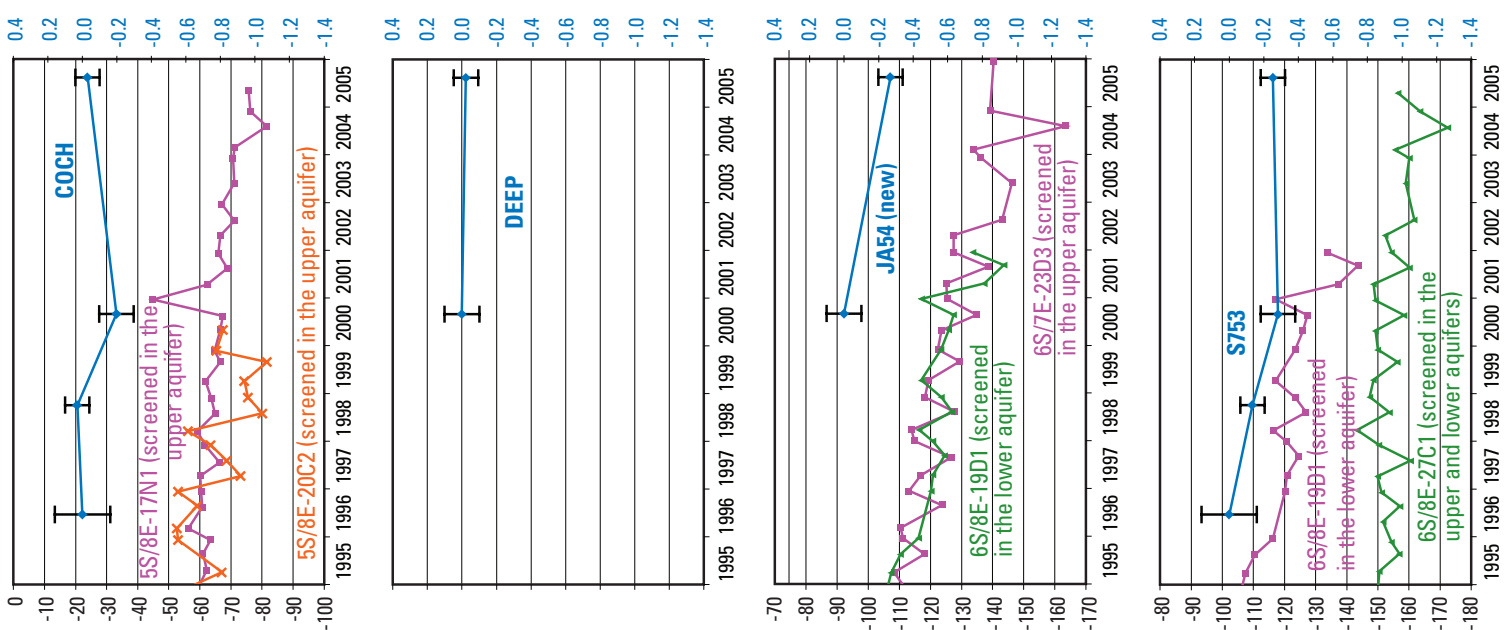

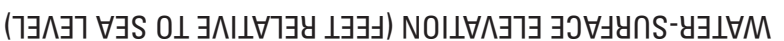

( IN JW
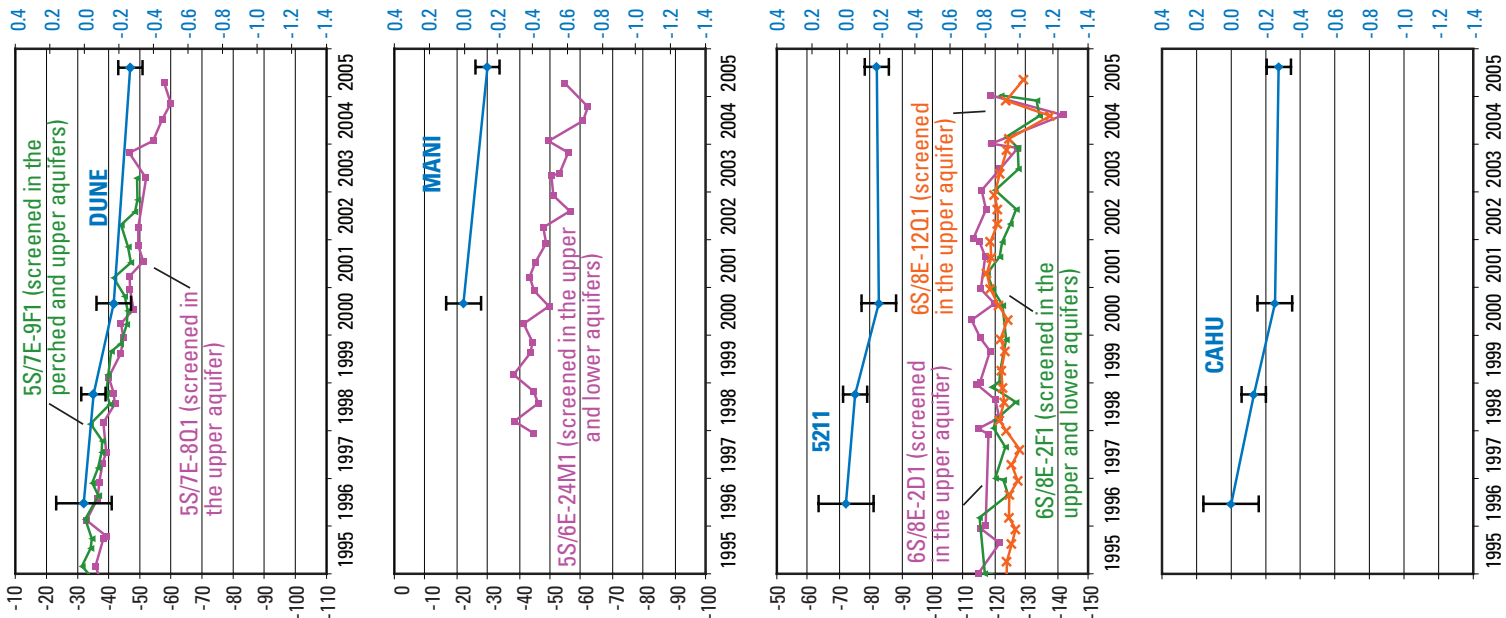

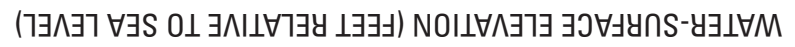

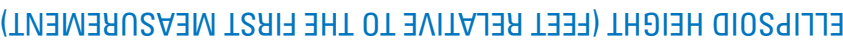
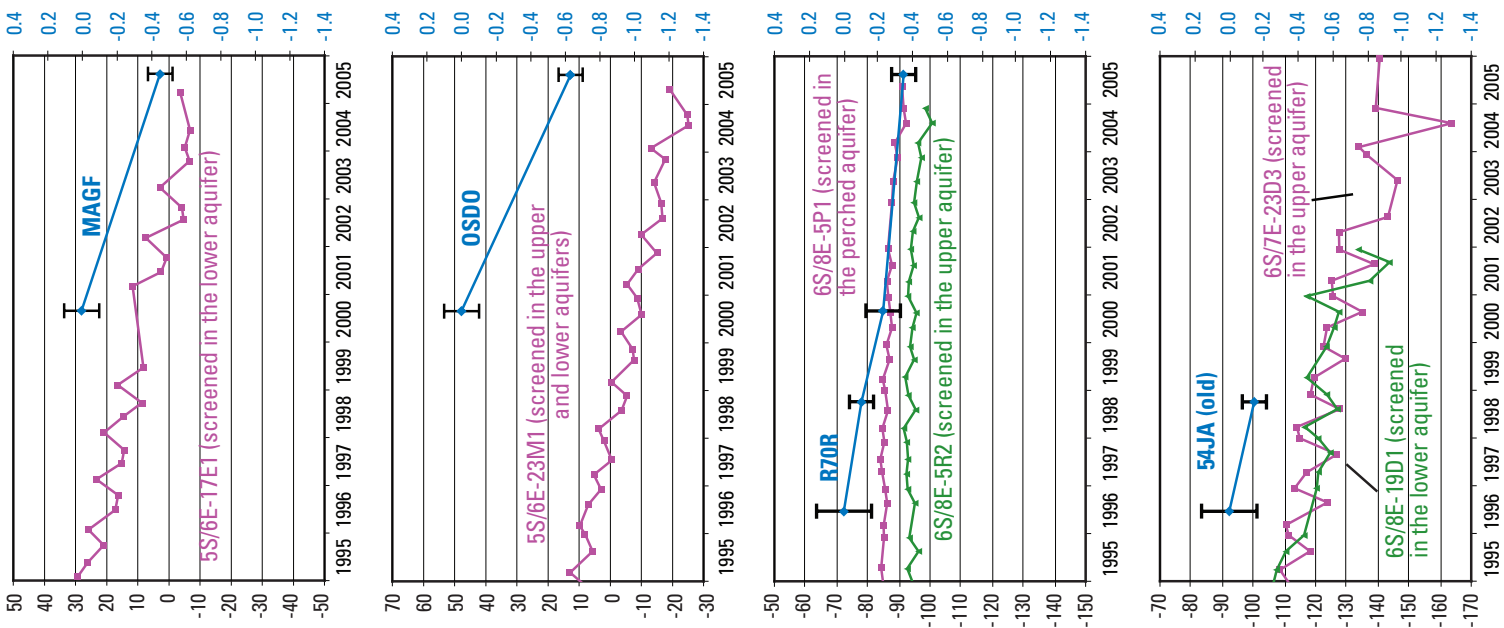

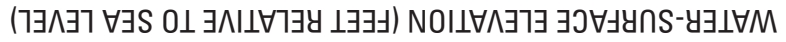

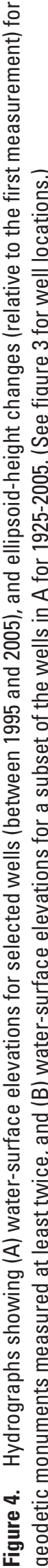




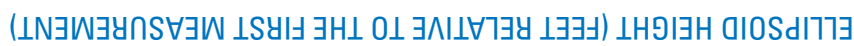

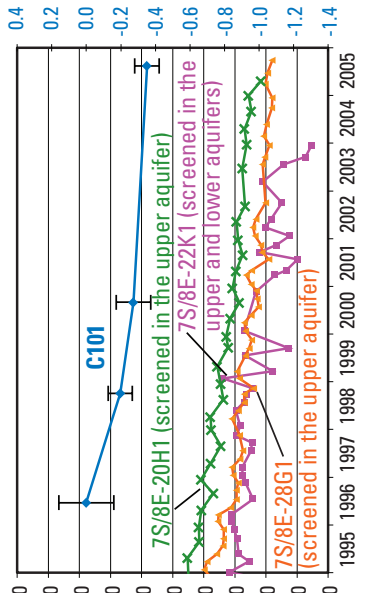

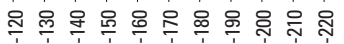
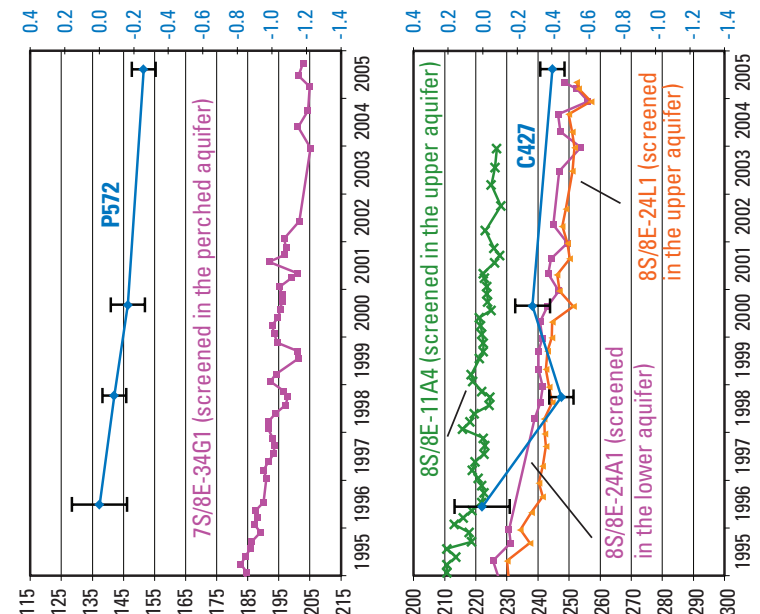

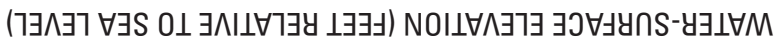

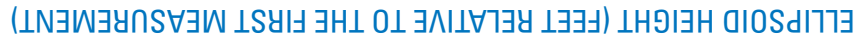

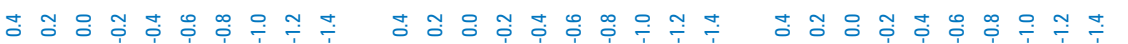

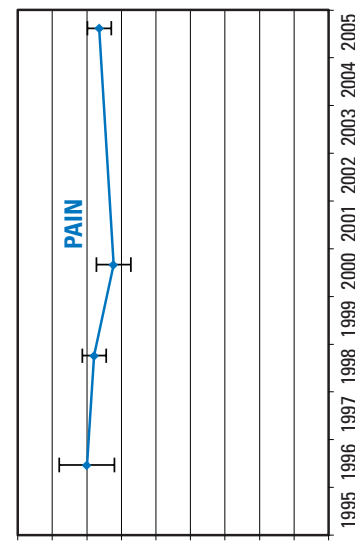

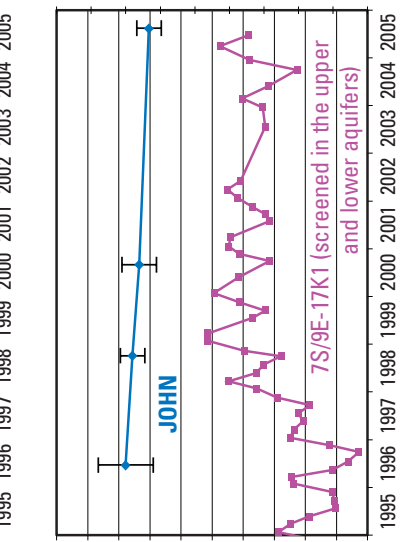

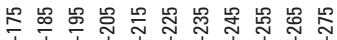

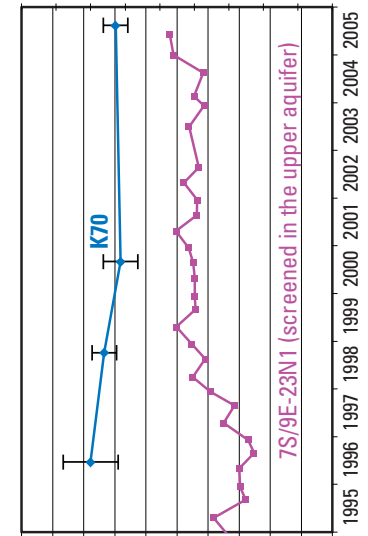

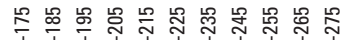

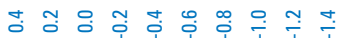

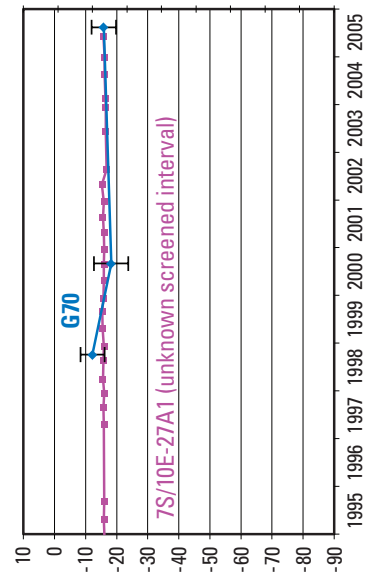

(

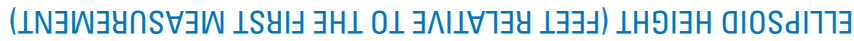

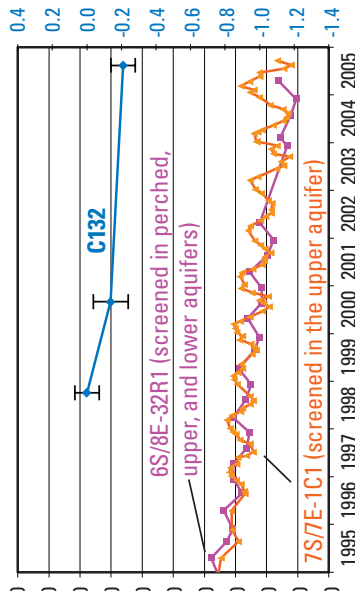

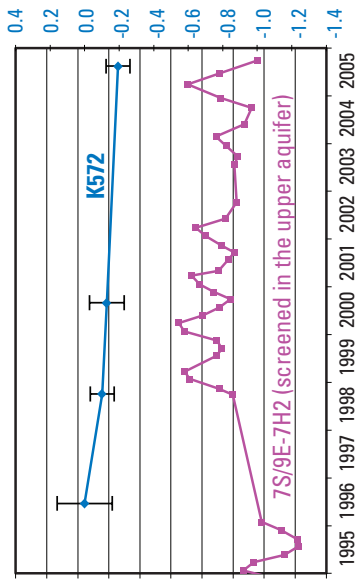

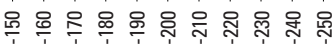

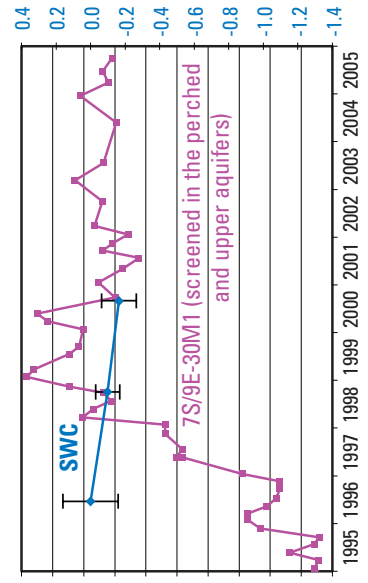

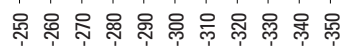

( 


\section{B}

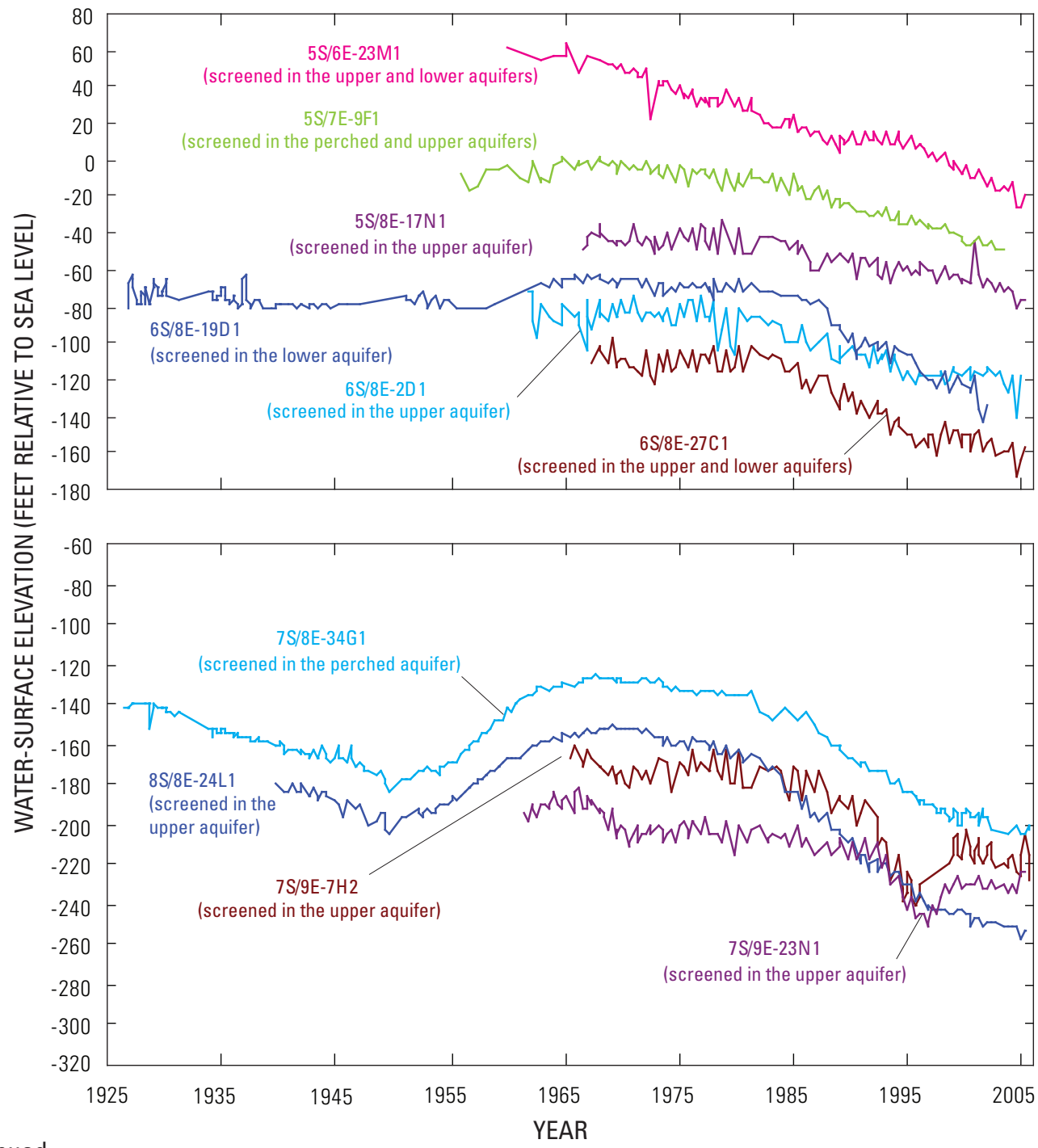

Figure 4. Continued.

PAIN, C132, K572, JOHN, C101, K70, P572, G70, and C427) did not exceed the maximum expected uncertainty of $\pm 36 \mathrm{~mm}$ $( \pm 0.12 \mathrm{ft})$ at the 95 -percent confidence level, indicating that the vertical positions of these monuments in August 2000 and in August 2005 were similar.

GPS measurements were made at 16 geodetic monuments (DUNE, COCH, R70R, 5211, CAHU, S753, C132, PAIN, C101, K572, JOHN, P572, SWC, K70, C427, and G70) during at least 3 of the 4 surveys, thus permitting calculations and comparisons of subsidence rates. A seventeenth monument, 54JA, was surveyed in 1996 and 1998 and was then replaced with monument JA54 (about $6 \mathrm{~m}$ [20 ft] northwest from 54JA) for the 2000 and 2005 surveys; although the monument location was changed slightly, rates of subsidence were compared. Because GPS data indicated that the heights of PAIN, JOHN, K70, SWC, and G70 were fairly stable (fig. $4 \mathrm{~A}$ ), the subsidence rates of the other 12 monuments are discussed. Eleven of the twelve monuments (DUNE, $\mathrm{COCH}$, R70R, 5211, 54JA/JA54, CAHU, S753, C132, C101, K572, and P572) show decreased subsidence rates between 2000 and 2005 compared with the subsidence rates between 1998 and 2000 , a period when the largest rates were computed at these 11 monuments (fig. 4A). The most marked subsidence-rate decreases between these two periods occurred at monuments $\mathrm{COCH}, 5211, \mathrm{CAHU}$, and S753, and the least marked subsidence-rate changes occurred at 54JA/JA54. Subsidence rates between 2000 and 2005 at DUNE, R70R, and P572 decreased by factors ranging from 2 to 3 , and $\mathrm{C} 132$ decreased by a factor of about 5 , compared to rates between 1998 and 2000. Calculated subsidence rates at monuments C101 and K572 continually decreased during 1996-2005. GPS results for the twelfth monument - C 427 - indicated subsidence between 1996 and 1998 and between 2000 and 2005, and uplift between 1998 and 2000, resulting in insignificant vertical position differences between 1998 and 2005. A power pole adjacent to $\mathrm{C} 427$ may have degraded the quality of the GPS observations; it is suspected that GPS observations at C427 had higher-than-expected errors. 


\section{Ground-Water Levels}

In the northwestern part of the geodetic network (near MANI, MAGF, OSDO, R70R, and JA54), where significant land subsidence was measured by 2005, and near DUNE, where small amounts of subsidence were measured by 2005, water levels generally showed seasonal fluctuations superimposed on longer-term water-level declines during 1995-2005 (fig. 4A). In the northeastern part of the network, at $\mathrm{COCH}$, where significant uplift was measured by 2005 , water levels in nearby wells also showed seasonal fluctuations superimposed on longer-term water-level declines during 1995-2005 (fig. 4A). However, wells 5S/8E-17N1 and 5S/8E$20 \mathrm{C} 2$, in which water levels were measured near $\mathrm{COCH}$, are on the west side of the San Andreas Fault (fig. 4A) and the geodetic monument $\mathrm{COCH}$ is on the east side of the fault (fig. 3); thus, hydrologic conditions in the two wells probably do not represent hydrologic conditions at $\mathrm{COCH}$.

In the southwestern part of the network near monuments C101, C132, P572, S753, and C427, where small amounts of subsidence were measured by 2005 , water levels showed seasonal fluctuations superimposed on longer-term water-level declines during 1995-2005 (fig. 4A).

In the southeastern part of the network near K572, JOHN, $\mathrm{K} 70$, and $\mathrm{G} 70$, and in the northeastern part of the network near 5211, where small or insignificant changes in elevation occurred, water levels generally showed seasonal variability superimposed on fairly stable or rising water levels during 1995 and 2005 (fig. 4A).

The relationship between ground-water-level changes and concurrent vertical changes at the geodetic monuments is not clearly defined. Complications that contribute to the difficulty in deciphering the relationship include the low frequency of both GPS and water-level measurements, and the complex, often significantly delayed mechanical responses of the aquifer system to ground-water-level changes. However, the locations of the monuments that subsided between 1996 and 2005 are coincident with areas where water levels generally declined during this period and during most of the last century (fig. 4). Similarly, the locations of the monuments that were fairly stable between 1996 and 2005 are coincident with areas where water levels generally were stable or recovered during this period. The coincident areas of subsidence and declining water levels, and of elevation stability and stable or recovering water levels, indicate that aquifer-system compaction may be causing subsidence. In the areas of subsidence, if water levels have declined sufficiently such that the effective stresses exceeded the preconsolidation stresses as is suggested by the historically low water levels shown in figure 4B, the subsidence may be permanent. Although this longer term relationship seems more straightforward, tectonically-induced subsidence also occurs on longer time scales. However, the CGPS stations used as constraints for each of the GPS datasets were fairly stable between 1996 and 2005, indicating that tectonic-induced vertical crustal motion was not included in the subsidence measurements at the geodetic monuments in the network.

\section{InSAR Methodology}

Using Interferometric Synthetic Aperture Radar (InSAR) is an effective way to measure vertical changes of land surface. InSAR is a satellite-based remote sensing technique that can detect centimeter-level ground-surface deformation over a $100 \mathrm{~km}^{2}$ area with a spatial resolution of $90 \mathrm{~m}$ or less. Synthetic Aperture Radar (SAR) imagery is produced by reflecting radar signals off a target area and measuring the two-way travel time between the target area and the satellite. InSAR uses two SAR scenes of the same area taken at different times and "interferes" (differences) them, resulting in maps called interferograms that show line-of-sight groundsurface displacement (range change) between the two time periods. The generation of an interferogram produces two components, amplitude and phase. The amplitude is the measure of the radar signal intensity returned to the satellite and shows roads, mountains, and other reflective features (similar to the image shown in fig. 5); the phase component is proportional to range change and shows the coherent displacements imaged by the radar (iggs. $6 \mathrm{~A}, \underline{7 \mathrm{~A}}, \underline{8 \mathrm{~A}}$ ). If the ground has moved away from (subsidence) or towards (uplift) the satellite between the times of the two acquisitions (the "timeline"), a slightly different portion of the wavelength is reflected back to the satellite resulting in a measurable phase shift that is proportional to range change. The map of phase shifts, or interferogram, is depicted with a repeating color scale that shows relative range change between the first and the second acquisitions. In this report, one complete color cycle (fringe) represents $28.3 \mathrm{~mm}(0.09 \mathrm{ft})$ of range change. Assuming all the motion is vertical, the indicated range change is about 90- to 95-percent of true vertical ground motion, depending on the satellite look angle and the location of the target area. The direction of change - subsidence or uplift-is indicated by the color progression of the fringe(s) from the outer edge of a deforming feature toward its center. For interferograms in this report, the color-fringe progression of yellow-green-blue-pink indicates subsidence; the opposite progression indicates uplift.

InSAR signal quality depends partly on satellite position, atmospheric effects, ground cover, land-use practices, and timeline of the interferogram. Strict orbital control is required to precisely control the look angle and position of the satellite. Successful application of the InSAR technique is contingent on looking at the same point on the ground from the same position in space so that the horizontal distance between each satellite pass, or perpendicular baseline, is minimized. Perpendicular baselines generally greater than about $200 \mathrm{~m}$ (656 ft) usually produce excessive topographic effects (parallax) that can mask the deformation signal. Phase shifts can be caused by varying atmospheric mass that is associated with different elevations. A digital elevation model (DEM) is used in the interferogram generation process to reduce the atmospheric effects caused by elevation differences (and also to georeference the image). Phase shifts also can be caused by 


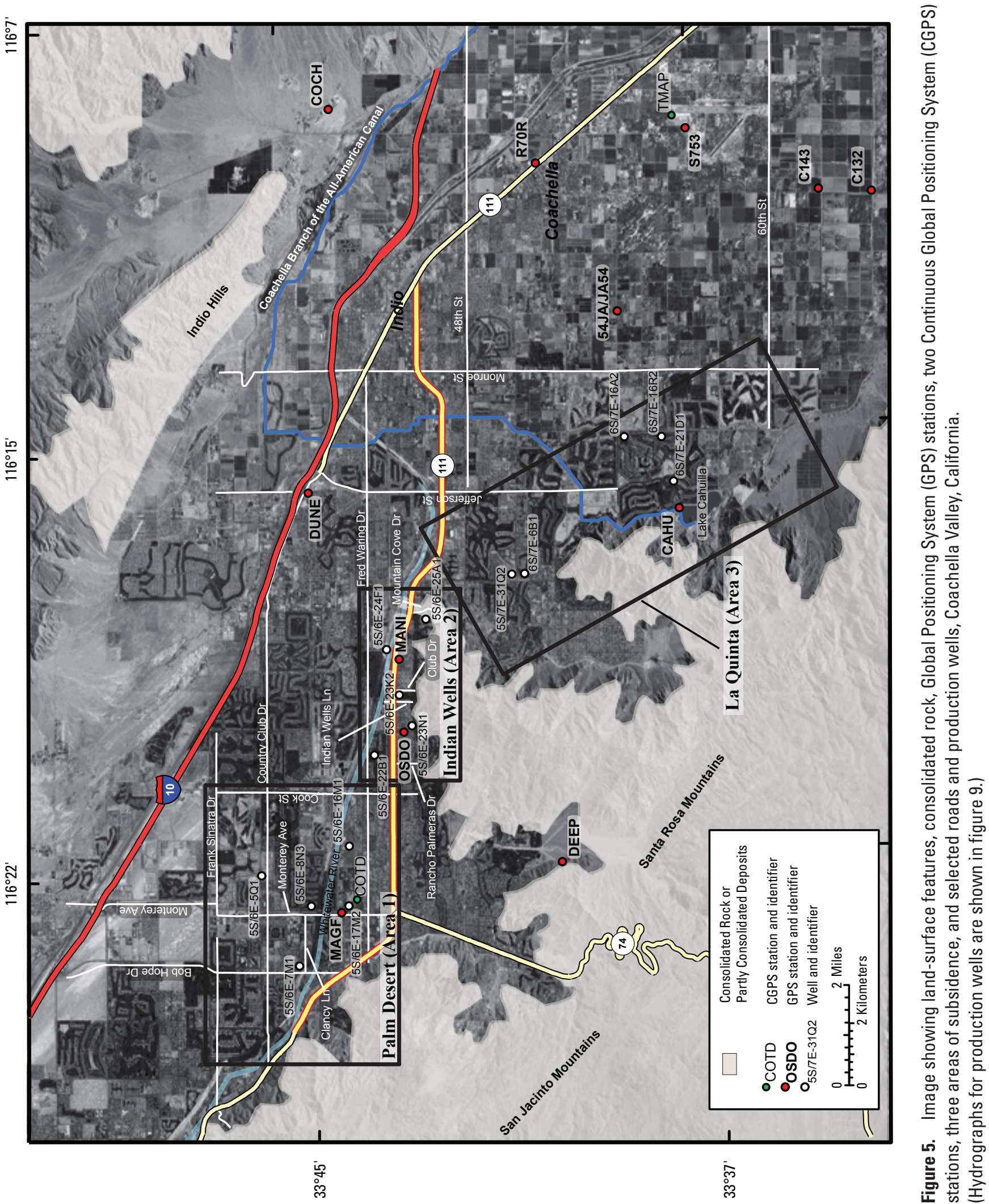




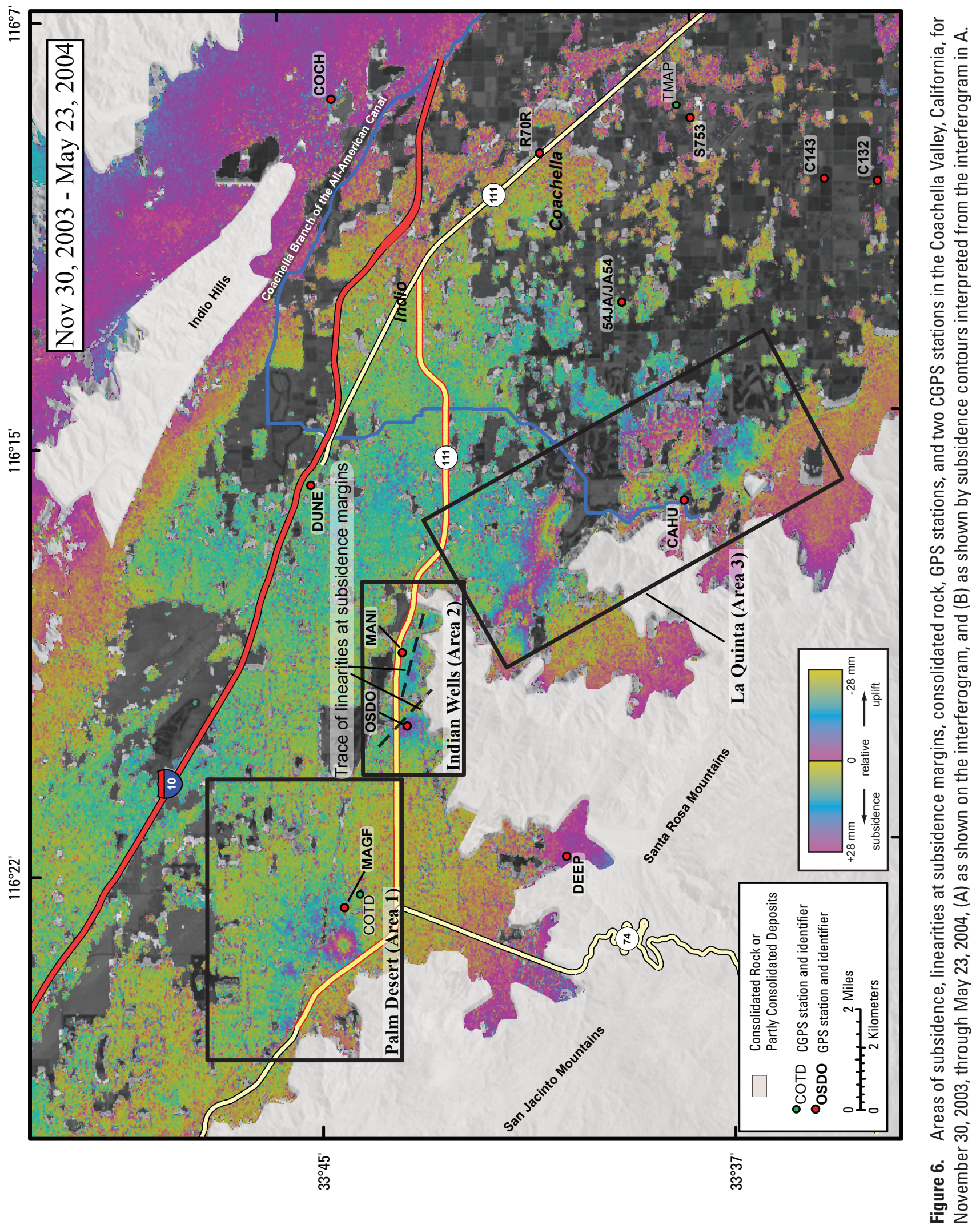




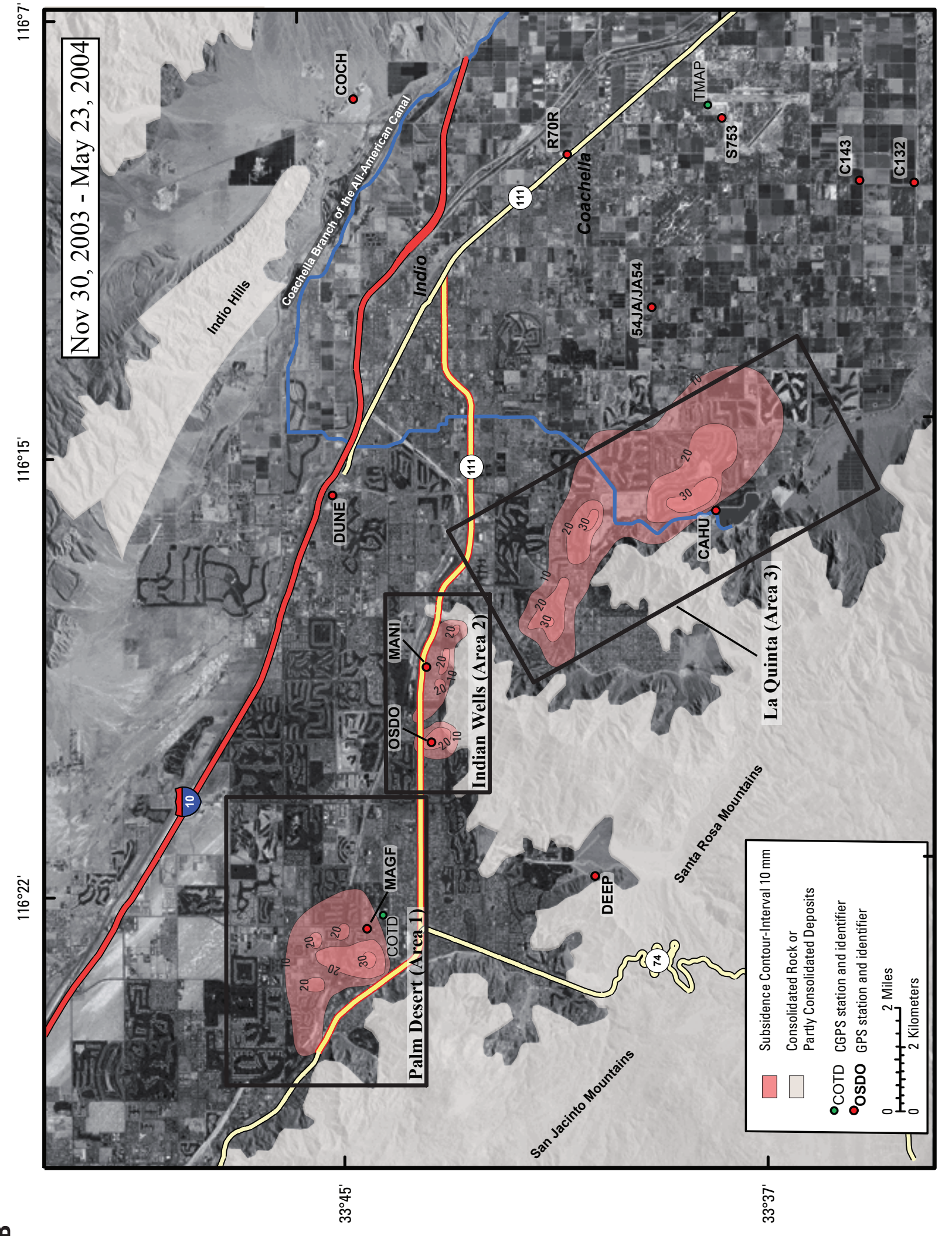

兽 


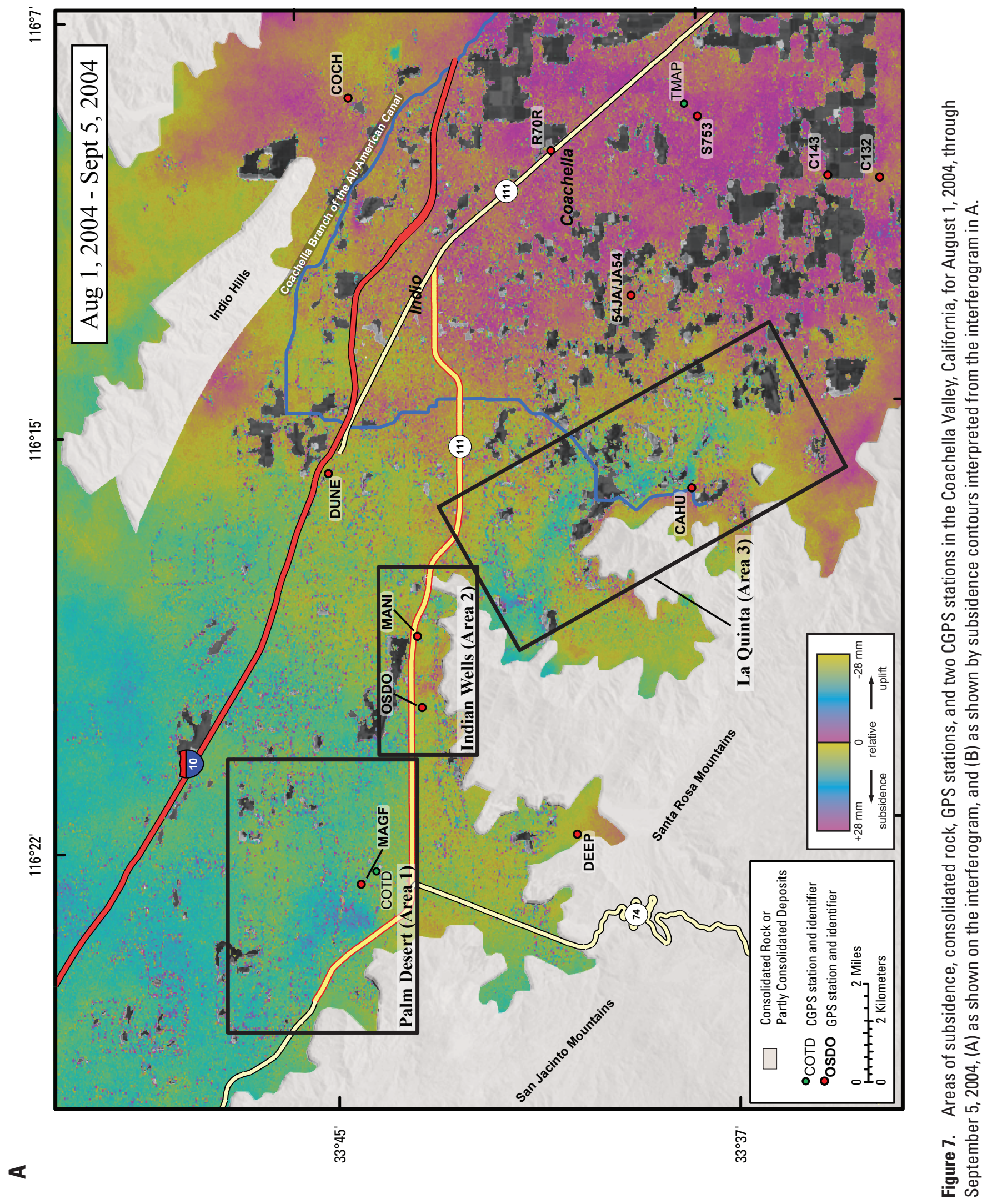




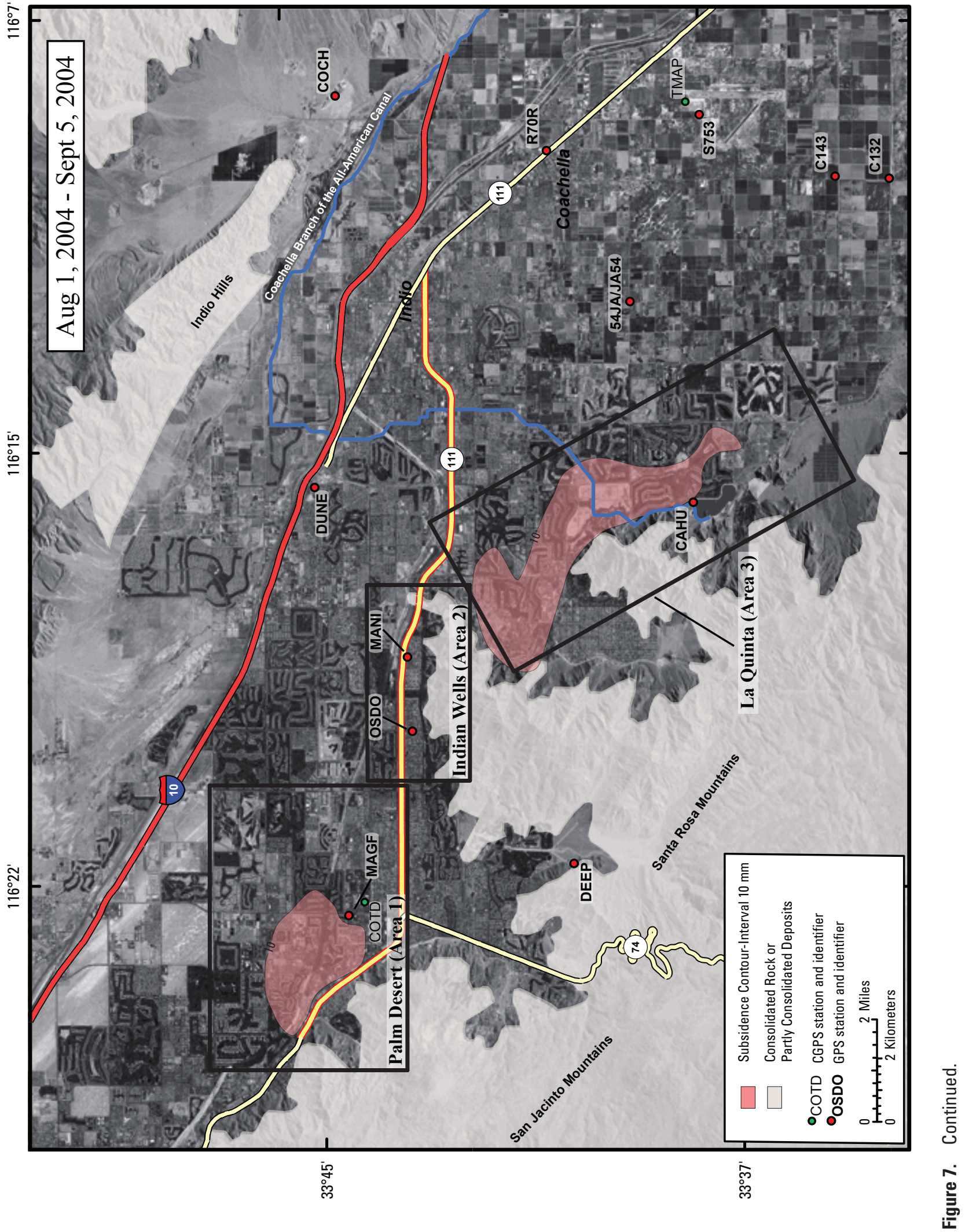




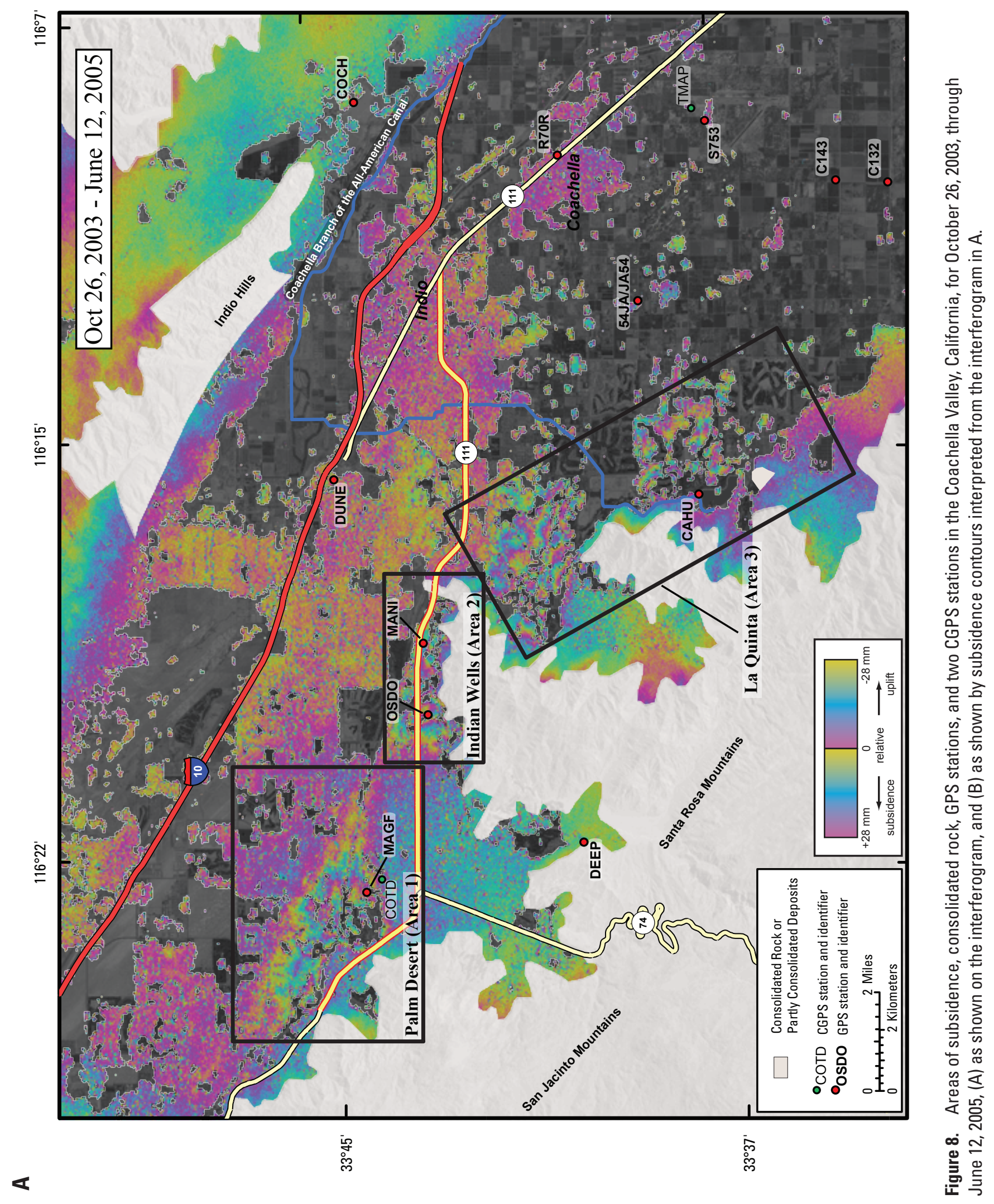




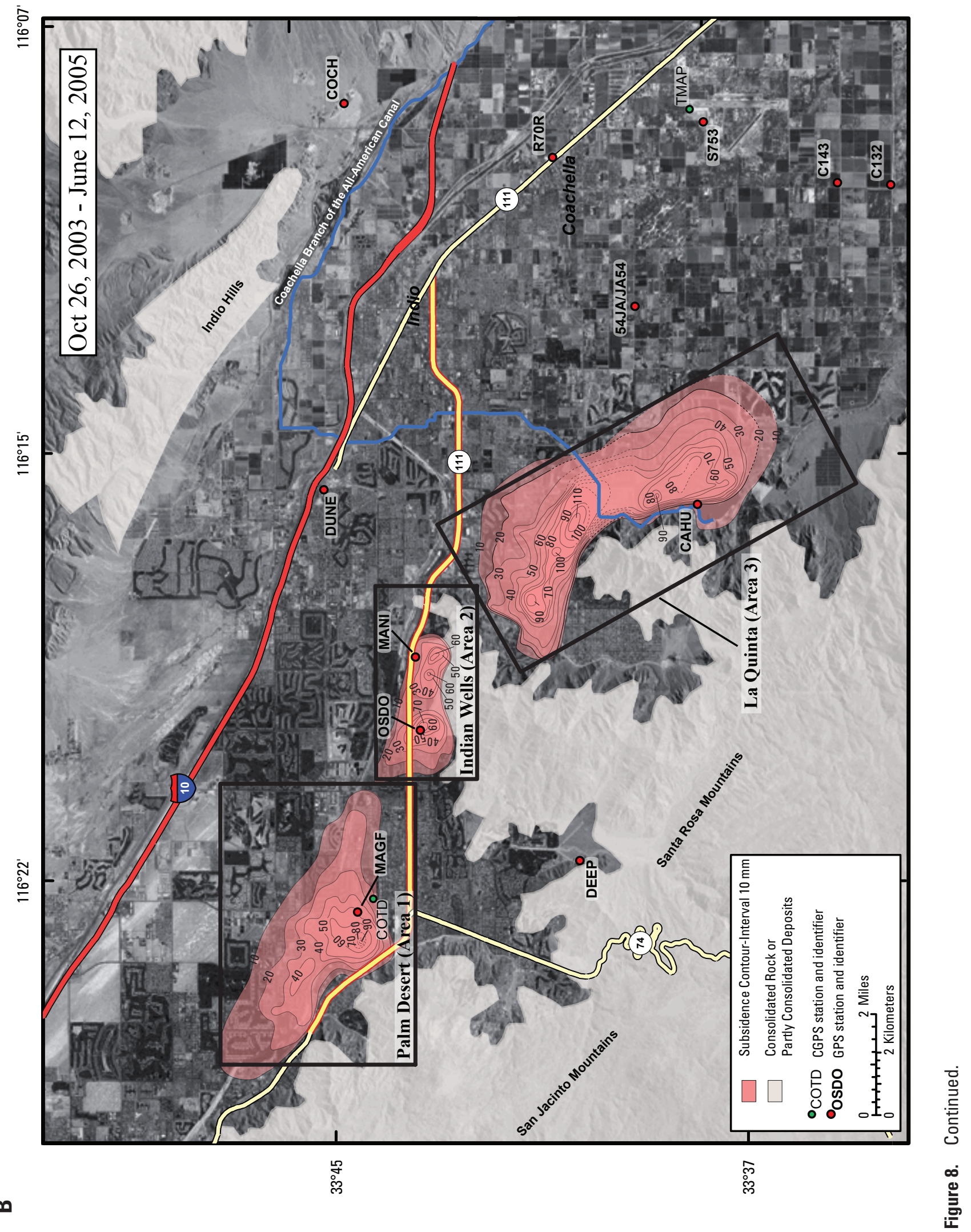


laterally variable atmospheric conditions such as clouds or fog, as the non-uniform distribution of water vapor differentially slows the radar signal over an image. Atmospheric artifacts can be identified by using several independent interferograms, which are defined as interferograms that do not share a common SAR image. When apparent ground motion is detected in only one interferogram, or a set of interferograms sharing a common SAR image, then the apparent motion likely is due to atmospheric phase delay or other error source and can be discounted.

The type and density of ground cover also can significantly affect interferogram quality. Densely forested areas are prone to reflect poor signals because the $\mathrm{C}$-band wavelength $(56.6 \mathrm{~mm}$ or $0.18 \mathrm{ft})$ cannot effectively penetrate thick vegetation and is either absorbed or reflected back to the satellite from varying depths within the canopy resulting in incoherent signal (shown as randomized colors on an interferogram). Sparsely vegetated areas and urban centers, however, generally reflect coherent signals because bare ground, roads, and buildings have high reflectivities and are relatively uniform during at least some range of InSAR timelines. Certain land-use practices, such as farming, which is prevalent in the Coachella Valley, also cause incoherent signal return. The tilling and plowing of farm fields causes large and nonuniform ground-surface change that cannot be resolved with InSAR. In both urban and non-urban areas, signal quality also is adversely affected by longer timelines, as there is more opportunity for nonuniform change and temporal decorrelation of the radar signal. Because Coachella Valley is fairly flat and contains several urban centers, the area lends itself to confident InSAR interpretations because most of the error sources are minimized. The agricultural fields in the area, however, cause significant InSAR signal incoherence that cannot be reliably interpreted using the coherent InSAR techniques described here.

Data from the European Space Agency's (ESA) ENVISAT satellite were obtained for analysis. The multimission ENVISAT platform was launched in 2002 and is currently (2007) the only ESA-owned fully functional SAR satellite. (The previous studies [Sneed and others 2001, 2002] used ESA's ERS-1 and -2 satellites; ERS-1 was turned off in 1999 and ERS-2 is no longer routinely suitable for interferometry). The satellite is side-looking and orbits the Earth at an altitude of approximately $800 \mathrm{~km}$ (500 mi), and has a 35-day repeat orbit. Twenty SAR images, acquired between February 26, 2003 and September 25, 2005, were used to produce 22 interferograms having timelines that range from 35 to 595 days. The three interferograms shown in this report were selected on the basis of overall interferogram quality and timeline length. Figures $6, \underline{7}$, and $\underline{8}$ show interferograms representing timelines ranging from 35 days to 595 days; the variable timelines demonstrate temporal decorrelation of an interferogram (coherency) and on subsidence feature characteristics, such as geographic extent.

\section{InSAR Results}

The interferograms of the Coachella Valley show significant land-surface-elevation changes in at least four areas. Land subsidence occurred in three of the areas-Palm Desert (Area 1), Indian Wells (Area 2), and La Quinta (Area 3) (figs. 6, 7, 8; table 2) - and both subsidence and uplift apparently occurred in one of the areas-Indio-Coachellabetween February 26, 2003, and September 25, 2005. The interferograms show that other local areas in the Coachella Valley also may have deformed (figs. $6, \underline{7}, \underline{8}$ ), but the extent of these areas and the amount of deformation generally are small compared with the three areas of land subsidence discussed in this section.

\section{Land Subsidence in the Palm Desert Area (Area 1)}

A subsidence signal was detected in Palm Desert (Area 1 in figs. $5,6,7,8$ ); this signal was previously detected by Sneed and others $(2001,2002)$ using InSAR methods. All 22 interferograms analyzed for this study show subsidence in this area (for example, figs $6, \underline{7}, \underline{8}$; table 2). The part of the signal that has the largest magnitude is nearly circular (slightly elongated north to south); in longer-term interferograms, it is as large as about $2 \mathrm{~km}(1.2 \mathrm{mi})$ in diameter and has an area of about $4 \mathrm{~km}^{2}\left(1.5 \mathrm{mi}^{2}\right)(\mathrm{fig} .8)$. This part of the signal is approximately bounded by Clancy Lane on the north, Fred Waring Drive on the south, Highway 111 and Bob Hope on the west, and Monterey Avenue on the east (fig. 5). The part of the signal that is smaller in magnitude extends to the north and east, has a pronounced northwest-southeast elongation, and has a much larger extent. The extent of this part of the signal is larger in interferograms representing longer timelines (fig. 8) than interferograms representing shorter timelines (fig. 7), but generally extends to the northwest where Frank Sinatra Drive intersects the Whitewater River channel, to the north beyond Country Club Drive, and to the east as far as Cook Street (fig. 5). The San Jacinto and Santa Rosa Mountains, which are outcropping consolidated rock, may act as barriers to subsidence farther to the south and southwest; and the Indio Hills, which are outcropping partly consolidated deposits, may act as barriers to subsidence farther to the northeast (figs. 2, 5). A lack of barriers to the northwest and southeast may explain the pronounced elongation of the subsidence signal in these directions. Several deformation timeseries can be constructed from InSAR data. The longest timeseries timeline (840 days) - May 7, 2003 to September 25, 2005was constructed using 3 interferograms (5/7/2003-9/8/2004; $9 / 5 / 2004-4 / 3 / 2005 ; 5 / 8 / 2005-9 / 25 / 2005)$ and indicates that about $180 \mathrm{~mm}(0.59 \mathrm{ft})$ of subsidence occurred in the Palm Desert area during this time - a rate of more than $6 \mathrm{~mm} / \mathrm{month}$ $(0.02 \mathrm{ft} /$ month) (Area 1 in figs. 5, 6, 7, 8, 9A). Sneed (2001; 


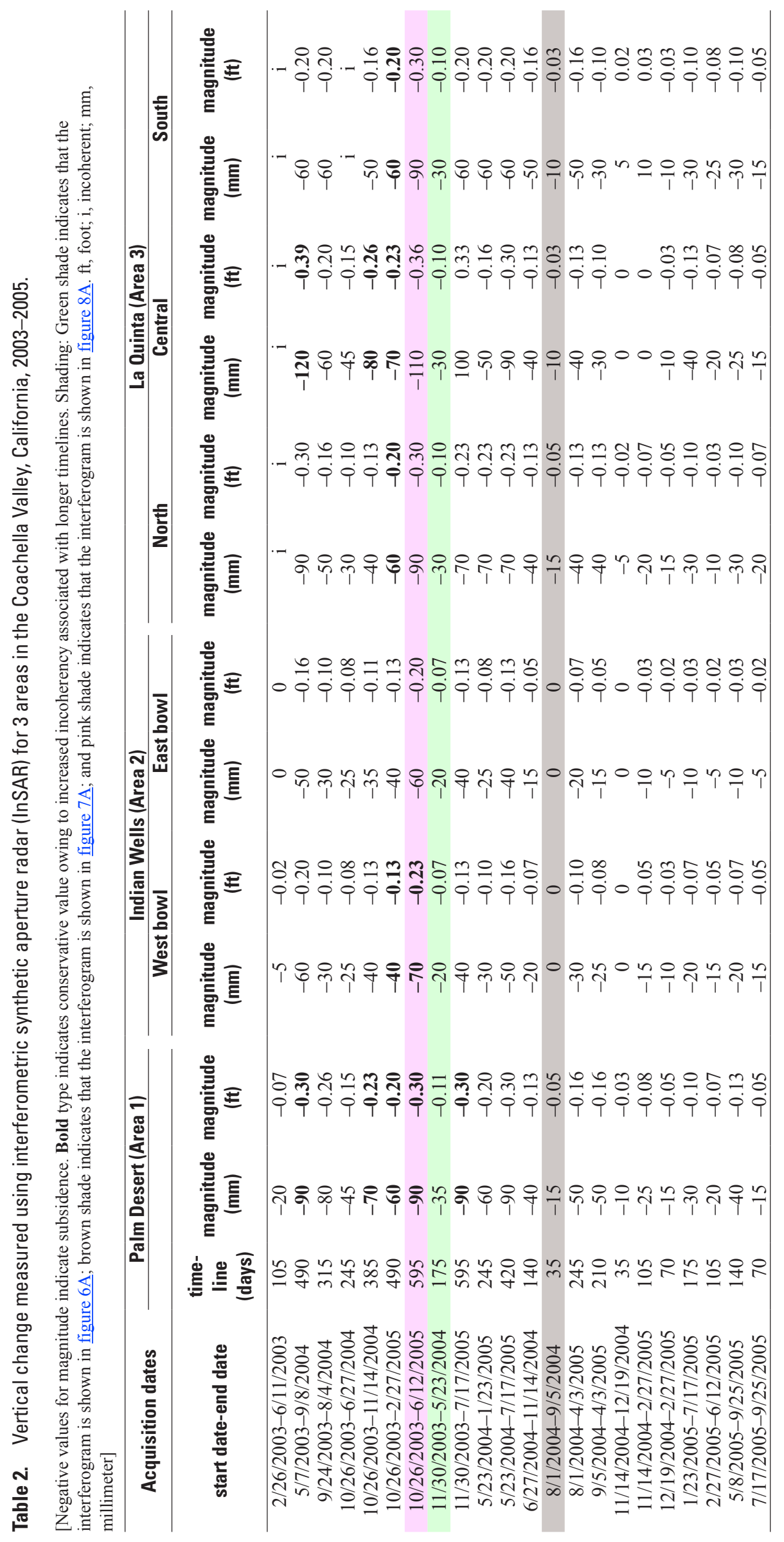


2002) reported that about $150 \mathrm{~mm}(0.49 \mathrm{ft})$ of subsidence occurred in this area during 1,541 days between 1996 and 2000 , which is equivalent to a rate of about $3 \mathrm{~mm} / \mathrm{month}$ $(0.1 \mathrm{ft} / \mathrm{month})$. These data indicate that subsidence rates have doubled since 2000 .

\section{Land Subsidence in the Indian Wells Area (Area 2)}

In the Indian Wells area, two distinct subsidence signals were detected, termed the western bowl and the eastern bowl (Area 2 in figs. 5, 6, 7, 8). Sneed and others (2002) discussed a possible additional subsidence signal as suspect about $1 \mathrm{~km}$ $(0.6 \mathrm{mi})$ southeast of the eastern subsidence bowl because of the proximity of this area to steep topographic terrain. The shorter timelines and multiple interferograms analyzed during this current study show that it is an extension of the eastern subsidence bowl (for example, fig. 6). Twenty of the 22 interferograms analyzed for this study show the western bowl and 19 show the eastern bowl (for example, figs 6, 8; table 2). The two interferograms with the shortest timelines (35 days) do not show either the western or eastern subsidence bowl (for example, fig. 7) and one interferogram of relatively low quality (not shown) with a 105-day timeline does not show the eastern bowl (table 2). The western subsidence bowl is approximately bounded by Fred Waring Drive on the north, the Santa Rosa Mountains on the south, Rancho Palmeras Drive on the west, and Indian Wells Lane on the east (fig. 5). The eastern subsidence bowl is approximately bounded by Highway 111 on the north, the Santa Rosa Mountains on the south, Club Drive on the west, and Mountain Cove Drive on the east (fig. 5). Distinct northwest-southeast linearities shown near the northern margins of the pair of subsiding bowls suggest the presence of barriers to ground-water flow or abrupt changes in lithology that control the northern extent of subsidence (fig. 6). The western bowl, which is elongated northwest-southeast, is as large as about $2.3 \mathrm{~km}$ (1.4 mi) long and about $1.8 \mathrm{~km} \mathrm{(1.1} \mathrm{mi)} \mathrm{wide} \mathrm{(northeast-}$ southwest) and has an area of about $4.1 \mathrm{~km}^{2}\left(1.6 \mathrm{mi}^{2}\right)$ in longer-term interferograms. The eastern bowl, which also is elongated northwest-southeast, is as large as about $2.3 \mathrm{~km}$ (1.4 mi) long and ranges from about 0.3 to $0.8 \mathrm{~km}(0.2$ to $0.5 \mathrm{mi}$ ) wide (northeast-southwest) and has an area of $1.2 \mathrm{~km}^{2}\left(0.5 \mathrm{mi}^{2}\right)$ (Area 2 in figures 6 and 8 ). The maximum subsidence for the western bowl was about $105 \mathrm{~mm}(0.34 \mathrm{ft})$ and for the eastern bowl was about $75 \mathrm{~mm}(0.25 \mathrm{ft})$ from May 7, 2003 to September 25, 2005 (fig. 9A); the equivalent rates are nearly $4 \mathrm{~mm} /$ month $(0.013 \mathrm{ft} / \mathrm{month})$ and nearly $3 \mathrm{~mm} /$ month $(0.01 \mathrm{ft} /$ month $)$ for the western and eastern bowls, respectively. Sneed $(2001 ; 2002)$ reported that about $80 \mathrm{~mm}(0.26 \mathrm{ft})$ of subsidence occurred in each bowl between 1996 and 2000; the equivalent rate is about $1.6 \mathrm{~mm} / \mathrm{month}$ $(0.005 \mathrm{ft} / \mathrm{month})$. These data indicate that subsidence rates have doubled since 2000 .

\section{Land Subsidence in the La Quinta Area (Area 3)}

A third area of subsidence was detected in the La Quinta area (Area 3 in figs. 5, 6, 7, 8). All 22 interferograms analyzed for this study show subsidence in this area (for example, figs. 6, 7, 8; table 2). Sneed and others (2002) analyzed 2 interferograms with timelines of 315 and 350 days and suggested Area 3 consisted of two separate areas of subsidence - termed the La Quinta and the Lake Cahuilla areas of subsidence - because the interferograms were not coherent throughout the area. Similarly for the interferograms analyzed for this current study, the longerterm interferograms were incoherent near the central part of the subsiding area (for example, figs. 6 and $\underline{8}$ ); however, the shorter-term interferograms show that this subsidence area likely is continuous, and is termed the La Quinta subsidence area for this report (for example, fig. 7A). The La Quinta subsidence area is about $10 \mathrm{~km}(6 \mathrm{mi})$ in length (northwestsoutheast) and is as much as $3 \mathrm{~km}(1.9 \mathrm{mi})$ in width. The area is approximately bounded by $48^{\text {th }}$ Street (if extended westward) on the north, $60^{\text {th }}$ Street (if extended westward) on the south, the Santa Rosa Mountains on the west, and streets varying from Jefferson Street to Monroe Street on the east (because the subsidence area trends northwest-southeast) (fig. 5). Different portions of this elongate subsidence bowl are subsiding at different rates; for May 7, 2003 to September 25,2005 , subsidence was $160 \mathrm{~mm}(0.52 \mathrm{ft})$ in the northern part, $175 \mathrm{~mm}(0.57 \mathrm{ft})$ in the central part, and $120 \mathrm{~mm}(0.39 \mathrm{ft})$ in the southern part (fig. 9A); equivalent subsidence rates are about $6 \mathrm{~mm} /$ month $(0.02 \mathrm{ft} / \mathrm{month})$ for the northern and central parts and more than $4 \mathrm{~mm} /$ month $(0.013 \mathrm{ft} /$ month $)$ for the southern part. Sneed (2002) reported that about $80 \mathrm{~mm}$ $(0.26 \mathrm{ft})$ of subsidence occurred in the northern part between 1998 and 2000 and is equivalent to a subsidence rate of more than $3 \mathrm{~mm} /$ month $(0.01 \mathrm{ft} /$ month). Sneed $(2001 ; 2002)$ reported that about $35 \mathrm{~mm}(0.11 \mathrm{ft})$ of subsidence occurred in the southern part between 1996 and 2000 and is equivalent to a subsidence rate of nearly $1 \mathrm{~mm} /$ month $(0.003 \mathrm{ft} /$ month $)$. These data indicate that subsidence rates have doubled in the northern part and increased by about a factor of 4 in the southern part since 2000 .

\section{Deformation in the Indio-Coachella Area}

Indio-Coachella has not been previously discussed as an area of deformation. The shorter timelines of InSAR data presented in this report as opposed to those presented in Sneed and others, 2001 and Sneed and others 2002, show land-surface-elevation changes in the Indio-Coachella area which appear to mostly be uplift or stable; however, the apparent deformation is suspect. As was mentioned in the InSAR Methodology section, interferograms show relative deformation, not absolute deformation. Because much of the 
basin is subsiding as is shown by the GPS results, it is likely that the Indio-Coachella area only appears to be uplifting as proximal areas in the basin are subsiding around it. The Indio-Coachella area could actually be subsiding at slower rates than proximal areas of the basin, which would appear as relative uplift in an interferogram. Because the deformation interpretations are suspect, this area is not discussed further in this report.

\section{Ground-Water Levels}

All the areas where significant subsidence was detected using InSAR - Palm Desert, Indian Wells, and La Quintacoincide with or are near areas where ground-water pumping generally caused ground-water levels to decline. Available water-level data indicate that water levels measured in 2005 in many wells in the Palm Desert, Indian Wells, and La Quinta areas were at the lowest levels in their recorded histories (fig. 9B). The coincident areas of the subsidence signals and the declining water levels, and the localized character of the subsidence signals typical of subsidence caused by localized pumping, strongly suggest a relation between subsidence and ground-water-level declines. The stresses imposed by the declining water levels and the significant subsidence at the three areas revealed by InSAR indicate that the water levels may have exceeded the preconsolidation stress, and if so, the subsidence may be permanent.

While ground-water-level data are too sparse to evaluate the short-term effect on vertical land-surface changes shown by the InSAR results, the available ground-water-level and InSAR data can be used to draw some inferences about the affected aquifer system. In Palm Desert (Area 1 in figs. 6, 7, 8), the area of maximum subsidence is concentric. Although water-level data are measured infrequently and are not available within the area of the concentric InSAR signal, data for the surrounding region indicate that waterlevel declines have been fairly uniform. The concentric subsidence shape suggests that the stress primarily causing the subsidence is near the center of the concentric shape and that sediments constituting the aquifer system in the area are fairly homogenous as the sediments responded uniformly to similar water-level declines in areas surrounding the center of the subsidence bowl.

In Indian Wells, the areas of subsidence form two separate elongated shapes - one parallel to and one perpendicular to the mountain front. The available water-level data indicate fairly uniform water-level declines in the area, suggesting that the aquifer system is heterogeneous in this part of the valley because sediments responded dissimilarly to similar water-level declines, as exhibited by the irregular shapes of the subsidence areas. Additional evidence of aquifer heterogeneity in the area is given by the distinct northwestsoutheast linearity shown on the northern margins of the pair of subsiding bowls, suggesting the presence of barriers to ground-water flow or abrupt changes in lithology that control the northern extent of subsidence (Area 2 in fig. 6).

In La Quinta, water-level data are too sparse to relate to the aquifer-system response, but the northwestern part of the subsiding area has an irregular shape that appears to be related to the contact between the alluvial aquifer and the bedrock basement complex that defines the extent of the aquifer system (Area 3 in figs. 6, 7, $\underline{8}$ ).

\section{Comparison of InSAR and GPS Results}

GPS and InSAR measurements can be compared at monuments MAGF, MANI, and OSDO, and at the CGPS station COTD in Palm Desert (figs. 3, 5, 6, 7, 8). InSAR data are uninterpretable at the other monuments in the landsubsidence monitoring network and at CGPS station TMAP (near S753) because they are in and near agriculturally active areas (which degrades the InSAR data). Because SAR data and GPS data for MAGF, MANI, and OSDO were not collected simultaneously, magnitudes of land subsidence measured by the two methods could not be compared; instead, rates of subsidence were compared at these monuments. Rates of land subsidence that were derived from GPS data measured at GPS monuments were calculated by differencing the ellipsoid heights computed from the GPS surveys in 2000 and 2005 and dividing by 1,813 days - the number of days between August 30, 2000 and August 17, 2005. Rates of land subsidence derived from InSAR data for the locations of GPS monuments were computed by determining the magnitude of land subsidence for each interferogram near each monument, then dividing that magnitude by the number of days that the interferogram spans; 22 subsidence rates (between February 26, 2003 and September 25, 2005) were calculated from the 22 interferograms analyzed. At COTD, absolute magnitudes of subsidence derived from GPS data and InSAR data were compared because continuously collected GPS data permits computation of a position for any day of interest.

At MAGF, $138 \mathrm{~mm}(0.45 \mathrm{ft})$ of subsidence was calculated from the GPS data, resulting in a calculated subsidence rate of $0.08 \mathrm{~mm} / \mathrm{d}\left(2.6 \times 10^{-4} \mathrm{ft} / \mathrm{d}\right)$. The subsidence rates calculated from InSAR data ranged from $0.06 \mathrm{~mm} / \mathrm{d}$ to $0.14 \mathrm{~mm} / \mathrm{d}\left(2.0 \times 10^{-4} \mathrm{ft} / \mathrm{d}\right.$ to $\left.4.6 \times 10^{-4} \mathrm{ft} / \mathrm{d}\right)$; the average calculated subsidence rate was $0.08 \mathrm{~mm} / \mathrm{d}\left(2.6 \times 10^{-4} \mathrm{ft} / \mathrm{d}\right)$ and the standard deviation was $0.03 \mathrm{~mm} / \mathrm{d}\left(9.8 \times 10^{-5} \mathrm{ft} / \mathrm{d}\right)$. At MANI, $46 \mathrm{~mm}(0.15 \mathrm{ft})$ of subsidence was calculated from the GPS data, resulting in a calculated subsidence rate of $0.03 \mathrm{~mm} / \mathrm{d}\left(9.8 \times 10^{-5} \mathrm{ft} / \mathrm{d}\right)$; the calculated subsidence rates derived from InSAR data ranged from $0 \mathrm{~mm} / \mathrm{d}(0 \mathrm{ft} / \mathrm{d})$ to $0.07 \mathrm{~mm} / \mathrm{d}\left(2.3 \times 10^{-4} \mathrm{ft} / \mathrm{d}\right)$; the average and standard deviation were $0.02 \mathrm{~mm} / \mathrm{d}\left(6.6 \times 10^{-5} \mathrm{ft} / \mathrm{d}\right)$. At OSDO, $192 \mathrm{~mm}(0.63 \mathrm{ft})$ of subsidence was calculated from the GPS data, resulting in a calculated subsidence rate of $0.11 \mathrm{~mm} / \mathrm{d}\left(3.6 \times 10^{-4} \mathrm{ft} / \mathrm{d}\right)$; the calculated subsidence rates derived from InSAR data 
A

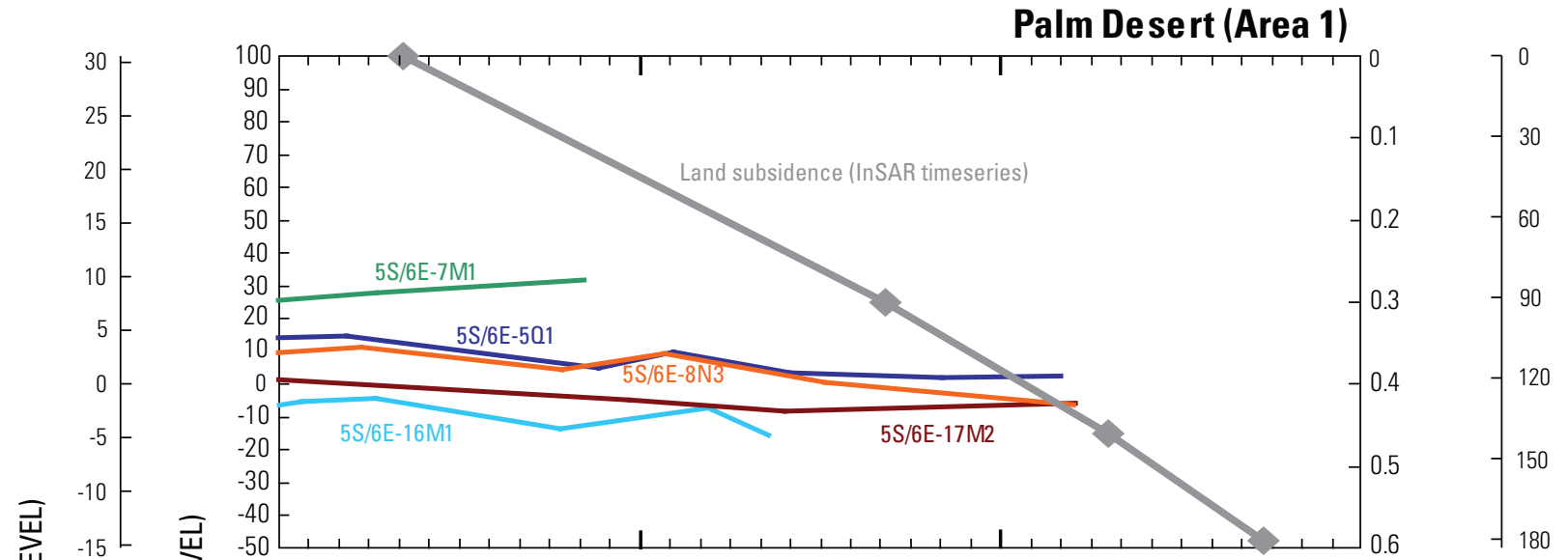

Indian Wells (Area 2)

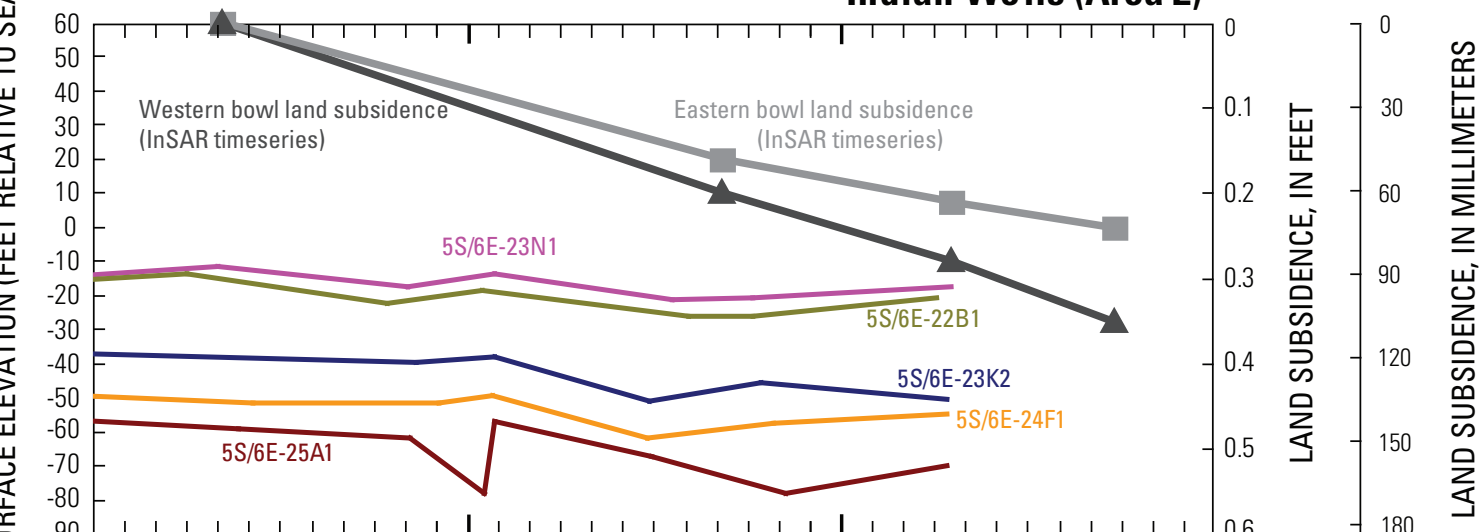

妾 $-105 \longleftrightarrow$
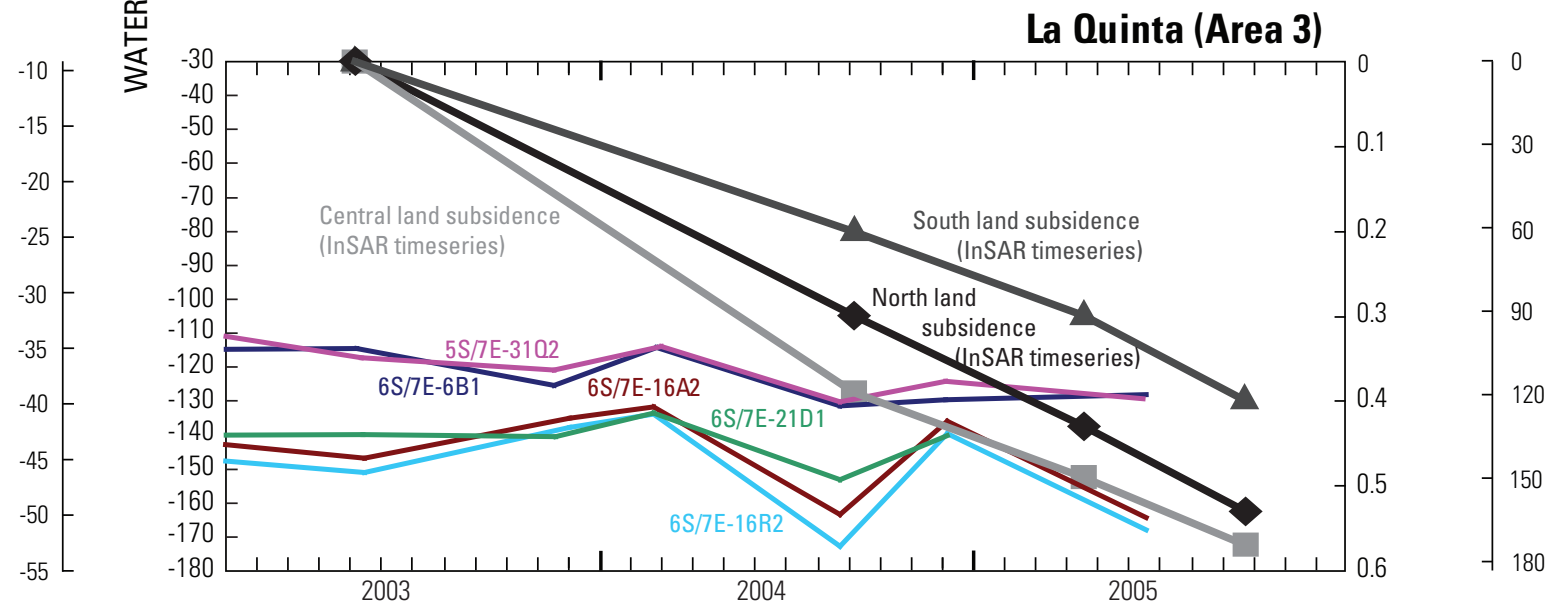

Figure 9. Hydrographs showing $(A)$ water-surface elevations for selected production wells, and InSAR timeseries showing land subsidence for 5/7/2003-9/25/2005, and (B) water-surface elevations for the same production wells for 1970-2005 in the three InSARdetected land subsidence areas in the Coachella Valley, California.

(See figure 5 for well locations.) 
B

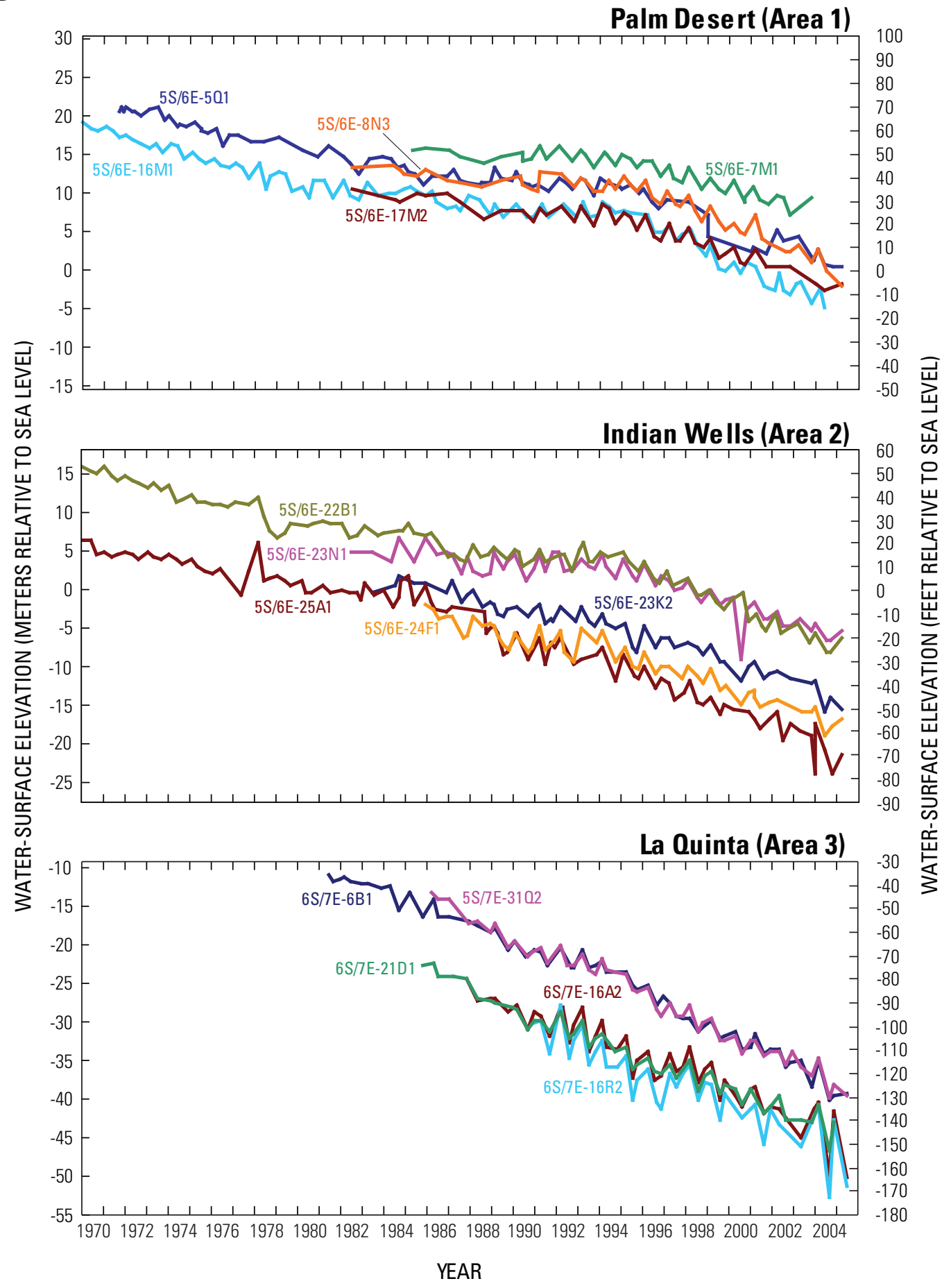

Figure 9. Continued. 
ranged from $0.05 \mathrm{~mm} / \mathrm{d}$ to $0.21 \mathrm{~mm} / \mathrm{d}\left(1.6 \times 10^{-4} \mathrm{ft} / \mathrm{d}\right.$ to $6.9 \mathrm{x}$ $\left.10^{-4} \mathrm{ft} / \mathrm{d}\right)$; the average was $0.11 \mathrm{~mm} / \mathrm{d}\left(3.6 \times 10^{-4} \mathrm{ft} / \mathrm{d}\right)$ and the standard deviation was $0.05 \mathrm{~mm} / \mathrm{d}\left(1.6 \times 10^{-4} \mathrm{ft} / \mathrm{d}\right)$.

The coordinates for CGPS station COTD were computed by SOPAC for the dates May 7, 2003, and September 25, 2005, and were compared to the InSAR time series that spans those same dates. GPS observations indicated $24 \mathrm{~mm}(0.08 \mathrm{ft})$ of subsidence, while InSAR measurements indicated $25 \mathrm{~mm}$ $(0.08 \mathrm{ft})$.

The calculated subsidence rates for monuments MAGF, MANI, OSDO, and the subsidence magnitude at COTD calculated using both GPS data and InSAR data compare favorably, thereby improving confidence in results derived from both methods. The favorable comparison of data for these monuments lends credibility to the GPS data collected at the other monuments in the network where InSAR data is unusable because of incoherence caused by agricultural land use.

\section{Future Monitoring}

Continued monitoring in the southern Coachella Valley is warranted because ground-water levels continue to decline to record-low levels in some areas of the valley and, therefore, the significant amounts and rising rates of land subsidence documented by this study are expected to increase. Most of the changes in the vertical positions of the GPS network monuments measured in 1996, 1998, and 2000 were within the measurement errors, indicating that a longer period of time would have been needed to see significant changes. Comparing the land-surface-elevation changes of the monuments in the GPS network in 2005 with those of the previous three surveys did show changes greater than the anticipated GPS measurement errors. As a result, GPS surveys completed every 3-5 years would be sufficient to monitor subsidence rates. Spatially detailed InSAR-derived maps of ground displacements, however, could continue to be processed annually or more frequently depending on data availability, because InSAR can detect relative changes in vertical position as small as $5 \mathrm{~mm}(0.02 \mathrm{ft})$ (Hoffmann and others, 2001). Because InSAR-detected areas of subsidence spatially overlap the GPS network, future monitoring of the GPS network could provide ground truth for the more spatially detailed and higher resolution InSAR measurements, as was done during this study. Furthermore, as InSAR technology matures, it is likely that some InSAR measurements made in agriculturally active areas, such as those in the southern Coachella Valley, could result in improved spatial detail of displacement in these areas.

The frequency of water-level measurements in wells in the Coachella Valley is too low to permit meaningful interpretations of the aquifer-system response to water-level changes, particularly when paired with the more frequent InSAR measurements. Furthermore, the wells generally have long or multiple screens such that the water-level measurement is a composite measurement representing a large thickness of the aquifer system. Increasing the measurement frequency of ground-water levels in just a few piezometers (wells constructed with short screens and small diameters for monitoring purposes) - both in areas of known subsidence and in areas of relative stability - would significantly improve analysis of the relationship between changes in water levels and in land-surface elevations. In concert with more frequent water-level measurements, more frequent and high-resolution measurements of aquifer-system compaction, such as those derived from a borehole extensometer, would improve the analysis of aquifer-system response. The information derived from such a monitoring site(s) would be useful in estimating aquifer-system hydraulic parameters that govern ground-water flow and land subsidence. This information could be used to construct a numerical model of ground-water flow and aquifer-system compaction to refine estimates of governing parameters and to predict potential aquifer-system compaction which could be used by CVWD to manage water resources while considering land subsidence.

\section{Summary}

Ground water has been a major source of agricultural, municipal, and domestic water supply in the Coachella Valley since the early 1920s. Ground-water levels declined throughout the Coachella Valley from the 1920s until 1949. In 1949, the importation of surface water from the Colorado River to the southern Coachella Valley began, resulting in decreased pumping and a recovery of water levels in some areas. Since the 1970s, the demand for water in the southern Coachella Valley has exceeded the deliveries of the imported surface water, and water levels have again declined. The declining water levels have the potential to induce or renew land subsidence in the Coachella Valley. Results of previous studies by the U.S. Geological Survey indicate that land subsidence may have been as much as about $150 \mathrm{~mm}(0.5 \mathrm{ft})$ in the southern parts of the valley between about 1930 and 1996 (Ikehara and others, 1997).

The location and magnitude of vertical land-surface changes during 1996-2005 were determined using GPS and InSAR techniques. The GPS measurements and the images processed for the InSAR measurements described in this report span the area from Palm Desert on the north to the Salton Sea on the south. GPS measurements were more useful than InSAR measurements for determining vertical land-surface changes in agricultural areas, and InSAR measurements were more useful for determining spatially detailed changes in nonagricultural areas. GPS measurements made at 13 geodetic monuments in 1996 and 2005 in the southern Coachella Valley indicate that the elevation of the land surface had a net decline of 124 to $9 \mathrm{~mm} \pm 54 \mathrm{~mm}$ ( 0.41 to $0.03 \mathrm{ft} \pm 0.18 \mathrm{ft}$ ) during the 9 -year period. Changes at 9 of the 13 monuments exceeded the maximum expected uncertainty of $\pm 54 \mathrm{~mm}( \pm 0.18 \mathrm{ft})$ at the 95 -percent confidence 
level, indicating that subsidence occurred at these monuments between June 1996 and August 2005. GPS measurements made at 20 geodetic monuments in 2000 and in 2005 indicate that the land-surface elevation changed -192 to $+51 \mathrm{~mm}$ $\pm 36 \mathrm{~mm}(-0.63$ to $+0.17 \mathrm{ft} \pm 0.12 \mathrm{ft})$ during the 5 -year period. Changes at 6 of the 20 monuments exceeded the maximum expected uncertainty of $\pm 36 \mathrm{~mm}( \pm 0.12 \mathrm{ft})$ at the 95 -percent confidence level - subsidence occurred at five monuments and uplift occurred at one monument between August 2000 and August 2005. Data from two of the five subsiding monuments for which subsidence rates could be compared indicate that subsidence rates decreased during this period compared with subsidence rates before 2000 .

Results of the InSAR measurements made between May 7, 2003, and September 25, 2005, indicate that land subsided about 75 to $180 \mathrm{~mm}(0.25$ to $0.59 \mathrm{ft})$ in three areas of the Coachella Valley: near Palm Desert, Indian Wells, and La Quinta; the equivalent subsidence rates range from about 3 to more than $6 \mathrm{~mm} /$ month ( 0.01 to $0.02 \mathrm{ft} /$ month). The subsiding areas near these locations were previously identified using InSAR measurements for 1996-2000, which indicated that land subsided about 35 to $150 \mathrm{~mm}(0.11$ to $0.49 \mathrm{ft})$ during the four-year period; the equivalent subsidence rates range from about 1 to $3 \mathrm{~mm} / \mathrm{month}$ ( 0.003 to $0.01 \mathrm{ft} / \mathrm{month})$. Comparison of the InSAR results indicates that subsidence rates have increased by 2 to 4 times since 2000 in these three areas.

Water-level measurements made at wells near the subsiding GPS monuments and near the areas of subsidence shown by InSAR generally indicate that water levels declined during 1996-2005. The relation between declining water levels and significant subsidence may indicate that the water levels have exceeded the preconsolidation stress and that the resulting subsidence may be permanent (inelastic). Continued monitoring in the southern Coachella Valley is warranted because ground-water levels continue to decline to recordlow levels in some areas of the valley and, therefore, the significant amounts and increasing rates of land subsidence documented by this study are expected to continue.

\section{Acknowledgments}

This study was done in cooperation with the CVWD; the authors gratefully acknowledge the CVWD for their support and assistance during this study. We acknowledge the SCIGN and its sponsors, the W.M. Keck Foundation, the National Aeronautics and Space Administration, the National Science Foundation, the USGS, and the Southern California Earthquake Center for providing data used in this study. We thank the University NAVSTAR Consortium (UNAVCO) for providing GPS equipment and exceptional technical support for the 2005 GPS Survey. Radar data used to produce the interferograms shown in this report were obtained from the European Space Agency for purposes of research and development.

\section{References}

Amelung, Falk, Galloway, D.L., Bell, J.W., Zebker, H.A., and Laczniak, R.J., 1999, Sensing the ups and downs of Las Vegas: InSAR reveals structural control of land subsidence and aquifer-system deformation: Geology, v. 27, no. 6, p. 483-486.

California Department of Water Resources, 1964, Coachella Valley Investigation: California Department of Water Resources, Bulletin 108, 145 p.

California Department of Water Resources, 1979, Coachella Valley area well standards investigation: Los Angeles, California Department of Water Resources, Southern District, $40 \mathrm{p}$.

Craymer, M.R., and Beck, N., 1992, Session versus baseline GPS processing, in the Proceedings of the 5th International Technical Meeting of the Institute of Navigation: Albuquerque, New Mexico, Institute of Navigation GPS-92, September 16-18, 1992.

Fielding, E.J., Blom, R.G., and Goldstein, R.M., 1998, Rapid subsidence over oil fields measured by SAR interferometry: Geophysical Research Letters, v. 25, p. 3215.

Galloway, D.L., Hudnut, K.W., Ingebritsen, S.E., Phillips, S.P., Peltzer, G., Rogez, F., and Rosen, P.A., 1998, InSAR detection of aquifer system compaction and land subsidence, Antelope Valley, Mojave Desert, California: Water Resources Research, v. 34, p. 2573-2585.

Galloway, D.L., Jones, D.R., and Ingebritsen, S.E., 1999, Land subsidence in the United States: U.S. Geological Survey Circular 1182, 175 p.

Galloway, D.L., Jones, D.R., and Ingebritsen, S.E., 2000, Measuring land subsidence from space: U.S. Geological Survey Fact Sheet 051-00, 4 p.

Hoffmann, J., Zebker H.A., Galloway, D.L., and Amelung, F., 2001, Seasonal subsidence and rebound in Las Vegas Valley, Nevada, observed by synthetic aperture radar interferometry: Water Resources Research, v. 37, no. 6, p. 1551-1566.

Holzer, T.L., 1984, Ground failure induced by ground-water withdrawal from unconsolidated sediment: Reviews in Engineering Geology, v. 6, p. 67-105.

Ikehara, M.E., Predmore, S.K., and Swope, D.J., 1997, Geodetic network to evaluate historical elevation changes and to monitor land subsidence in Lower Coachella Valley, California, 1996: U.S. Geological Survey Water-Resources Investigations Report 97-4237, scale 1:63,000, 1 sheet [folded in envelope]. 
Leake, S.A., and Prudic, D.E., 1991, Documentation of a computer program to simulate aquifer-system compaction using the modular finite-difference ground-water flow model: U.S. Geological Survey Techniques of WaterResources Investigations, book 6, chap A2, 68 p.

Massonnet, D., Briole, P., and Arnaud, A., 1995, Deflation of Mount Etna monitored by spaceborne radar interferometry: Nature, v. 375 , p. $567-570$.

Massonnet, D., Holzer, T., and Vadon, H., 1997, Land subsidence caused by the East Mesa geothermal field, California, observed using SAR interferometry: Geophysical Research Letters, v. 24, p. 901-904.

Massonnet, D., Rossi, M., Carmona, C., Adragna, F., Peltzer, G., Feigl, K., and Rabaute, T., 1993, The displacement field of the Landers earthquake mapped by radar interferometry: Nature, v. 364, p. 138-142.

McKibben, M.A., 1993, The Salton Trough rift, in Reynolds, R.E., and Reynolds, Jennifer, eds., Ashes, faults and basins: San Bernardino County Museum Association Special Publication, v. 93-1, p. 76-80.

Meinzer, O.E., 1928, Compressibility and elasticity of artesian aquifers: Economic Geology, v. 23, no. 3, p. 263-291.

Poland, J.F., ed., 1984, Guidebook to studies of land subsidence due to ground-water withdrawal, v. 40 of UNESCO Studies and Reports in Hydrology: Paris, France, United Nations Educational, Scientific and Cultural Organization, 305 p., 5 appendixes.

Riley, F.S., 1998, Mechanics of aquifer systems-The scientific legacy of Joseph F. Poland, in Borchers, J., ed., Land subsidence - Case Studies and Current Research: Proceedings of the Dr. Joseph F. Poland Symposium on Land subsidence, Association of Engineering Geologists Special Publication 8, p. 13-227.

Rosen, P.A., Hensley, Scott, Joughin, I.R., Li, F.L., Madsen, S.N., Rodriguez, Ernesto, and Goldstein, R.M., 2000, Synthetic aperture radar interferometry: Proceedings of the of Civil Engineers, v. 88, no. 3, p. 333-382.

Shen, Z.-K., Agnew, D.C., King, R.W., Dong, D., Herring, T.A., Wang, M., Johnson, H., Anderson, G., Nikolaidis, R., van Domselaar, M., Hudnut, K.W., and Jackson, D.D., 2003, The SCEC crustal motion map, Version 3.0, http:// epicenter.usc.edu/cmm3, accessed April 19, 2007.
Sneed, Michelle, Ikehara, M.E., Galloway, D.L., and Amelung, Falk, 2001, Detection and measurement of land subsidence using global positioning system and interferometric synthetic aperture radar, Coachella Valley, California, 1996-98: U.S. Geological Survey WaterResources Investigations Report 01-4193, 26 p.

Sneed, Michelle, Stork, S.V., and Ikehara, M.E. 2002, Detection and measurement of land subsidence using global positioning system and interferometric synthetic aperture radar, Coachella Valley, California, 1998-2000: U.S. Geological Survey Water-Resources Investigations Report 02-4239, $29 \mathrm{p}$.

Terzaghi, Karl, 1925, Principles of soil mechanics, IVSettlement and consolidation of clay: Engineering NewsRecord, 95 (3), p. 874-878.

Tyley, S.J., 1971, Analog model study of the ground-water basin of the upper Coachella Valley, California: U.S. Geological Survey Open-File Report, 89 p.

Zebker, H.A., Rosen, P.A., and Hensley, S., 1997, Atmospheric effects in interferometric synthetic aperture radar surface deformation and topographic maps: Journal of Geophysical Research, v. 102, p. 7547-7563.

Zilkoski, D.B., D’Onofrio, J.D., and Frakes, S.J., 1997, Guidelines for establishing GPS-derived ellipsoid heights, (Standards: $2 \mathrm{~cm}$ and $5 \mathrm{~cm}$ ) version 4.3: Silver Spring, Md., National Geodetic Survey, 10 p, 3 appendices. 
